University of Nebraska - Lincoln

DigitalCommons@University of Nebraska - Lincoln

\title{
Isotopic evidence for the diversity of late Quaternary loess in Nebraska: Glaciogenic and nonglaciogenic sources
}

John N. Aleinikoff

U.S. Geological Survey

Daniel R. Muhs

U.S. Geological Survey, dmuhs@usgs.gov

E. Arthur Bettis III

University of lowa, art-bettis@uiowa.edu

William C. Johnson

University of Kansas

C. Mark Fanning

Australian National University

See next page for additional authors

Follow this and additional works at: https://digitalcommons.unl.edu/usgsstaffpub

Part of the Earth Sciences Commons

Aleinikoff, John N.; Muhs, Daniel R.; Bettis, E. Arthur III; Johnson, William C.; Fanning, C. Mark; and Benton, Rachel, "Isotopic evidence for the diversity of late Quaternary loess in Nebraska: Glaciogenic and nonglaciogenic sources" (2008). USGS Staff -- Published Research. 161.

https://digitalcommons.unl.edu/usgsstaffpub/161

This Article is brought to you for free and open access by the US Geological Survey at DigitalCommons@University of Nebraska - Lincoln. It has been accepted for inclusion in USGS Staff -- Published Research by an authorized administrator of DigitalCommons@University of Nebraska - Lincoln. 


\section{Authors}

John N. Aleinikoff, Daniel R. Muhs, E. Arthur Bettis III, William C. Johnson, C. Mark Fanning, and Rachel Benton 


\title{
Isotopic evidence for the diversity of late Quaternary loess in Nebraska: Glaciogenic and nonglaciogenic sources
}

\author{
John N. Aleinikoff ${ }^{\dagger}$ \\ U.S. Geological Survey, MS 963, Denver, Colorado 80225, USA \\ Daniel R. Muhs \\ U.S. Geological Survey, MS 980, Denver, Colorado 80225, USA
}

E. Arthur Bettis III
Department of Geoscience, University of Iowa, Iowa City, Iowa 52242, USA

William C. Johnson

Department of Geography, University of Kansas, Lawrence, Kansas 66045, USA

C. Mark Fanning

PRISE, Research School of Earth Sciences, Australian National University, Canberra, ACT 0200, Australia

Rachel Benton

U.S. National Park Service, Badlands National Park, 25216 Ben Reifel Road, P.O. Box 6, Interior, South Dakota 57750, USA

\section{ABSTRACT}

$\mathrm{Pb}$ isotope compositions of detrital K-feldspars and U-Pb ages of detrital zircons are used as indicators for determining the sources of Peoria Loess deposited during the last glacial period (late Wisconsin, ca. $25-14 \mathrm{ka}$ ) in Nebraska and western Iowa. Our new data indicate that only loess adjacent to the Platte River has $\mathrm{Pb}$ isotopic characteristics suggesting derivation from this river. Most Peoria Loess in central Nebraska (up to $20 \mathrm{~m}$ thick) is non-glaciogenic, on the basis of $\mathrm{Pb}$ isotope ratios in K-feldspars and the presence of 34-Ma detrital zircons. These isotopic characteristics suggest derivation primarily from the Oligocene White River Group in southern South Dakota, western Nebraska, southeastern Wyoming, and northeastern Colorado. The occurrence of 10-25 Ma detrital zircons suggests additional minor contributions of silt from the Oligocene-Miocene Arikaree Group and Miocene Ogallala Group.

Isotopic data from detrital K-feldspar and zircon grains from Peoria Loess deposits in eastern Nebraska and western Iowa suggest that the immediate source of this loess was alluvium of the Missouri River. We conclude that this silt probably is of glaciogenic origin,

†E-mail: jaleinikoff@usgs.gov primarily derived from outwash from the western margin of the Laurentide Ice Sheet.

Identification of the White River Group as the main provenance of Peoria Loess of central Nebraska and the Missouri River valley as the immediate source of western Iowa Peoria Loess indicates that paleowind directions during the late Wisconsin were primarily from the northwest and west, in agreement with earlier studies of particle size and loess thickness variation. In addition, the results are in agreement with recent simulations of non-glaciogenic dust sources from linked climate-vegetation modeling, suggesting dry, windy, and minimally vegetated areas in parts of the Great Plains during the last glacial period.

Keywords: loess, zircon, K-feldspar, U-Pb, $\mathrm{Pb}$ isotopes.

\section{INTRODUCTION}

Loess, or windblown silt, is the most extensive surficial deposit in the central United States (Fig. 1) and is also abundant over parts of Alaska, China, Russia, South America, Europe, and New Zealand. Because many of these deposits record global climate changes during the past 2 million years, there is a renewed interest in loess as an important record of glacial and interglacial climates (Hovan et al., 1989; Zhisheng et al., 1990; Muhs et al., 1999b; Muhs and Bettis, 2003; Roberts et al., 2003).

In addition to indicating paleoclimate conditions, dust in transport may play a significant role in bringing about climate change. Depending on the size and composition of airborne particles, as well as the albedo of the surface over which dust is being transported, eolian silt can have either a cooling or warming effect on the atmosphere (Harvey, 1988; Tegen et al., 1996; Tegen and Lacis, 1996; Overpeck et al., 1996; Tegen, 2003; Bettis et al., 2003a; Roberts et al., 2003). Airborne dust can also have indirect effects on the atmosphere, such as cooling due to drawdown of atmospheric $\mathrm{CO}_{2}$ via dustfertilized growth of phytoplankton in the ocean (Young et al., 1991). Greater dust production during the last glacial period is likely based on ice sheet dynamics and production of silt-sized "rock flour" by glacial grinding (Hughes, 1992). However, atmospheric modeling of the last glacial period also suggests that greater aridity, a decreased intensity of the hydrologic cycle (such that dust could stay in suspension longer), decreased vegetation cover, and stronger winds may also have enhanced the flux of eolian silt (Andersen et al., 1998; Mahowald et al., 1999; Kohfeld and Harrison, 2000).

The observation of greater dust flux during the last glacial period due to climatic and biotic factors alone implies that there may have been non-glacial sources of loess (Mahowald et al.,

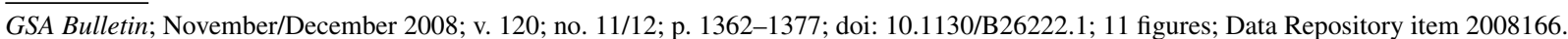




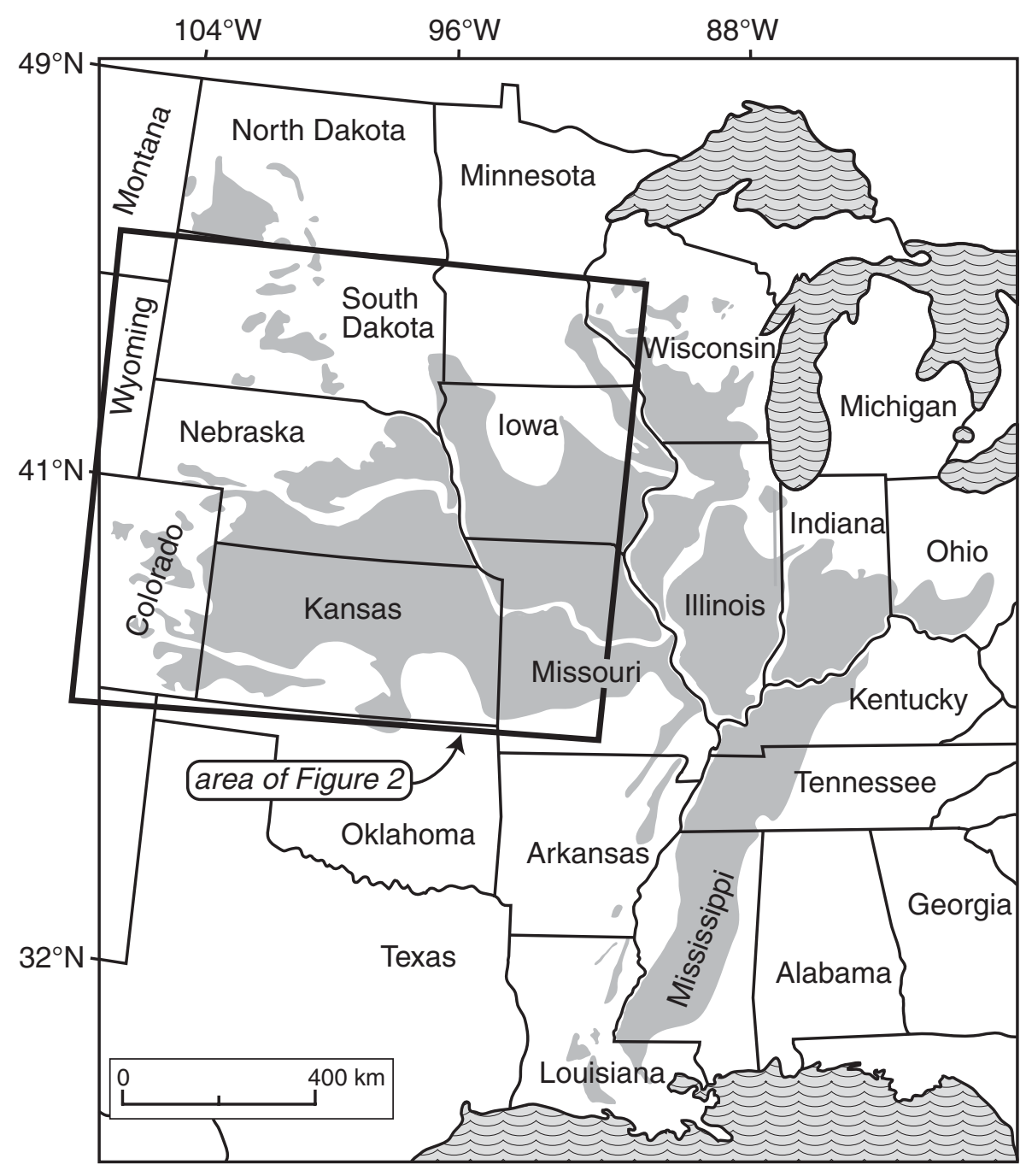

Figure 1. Distribution of late Wisconsin loess (gray shaded areas) in the central United States.

1999, 2006; Kohfeld and Harrison, 2001). The issue of "glacial" versus "desert" (i.e., non-glaciogenic) sources of loess has been debated by geomorphologists for more than $60 \mathrm{yr}$ (Bryan, 1945; Thorp, 1945; Smalley and Krinsley, 1978; Pye, 1987; Tsoar and Pye, 1987; Welch and Hale, 1987; Aleinikoff et al., 1999; Wright, 2001). Most workers accept the model that loess was derived from glaciofluvial outwash deposited in large valley trains in areas immediately south of the large ice sheets that covered North America and Europe (Ruhe, 1983; Smalley and Leach, 1978). Less certain, however, are the origins of extensive (at least 150,000 $\mathrm{km}^{2}$ ) and thick (up to nearly $50 \mathrm{~m}$ ) loess deposits found well away from the Laurentide Ice Sheet and major valley train sources, such as in the Great Plains region of North America (Fig. 1). Loess accumulations in this area were deposited about the same time as their glaciogenic counterparts farther east (Martin, 1993; Muhs et al., 1999a; Roberts et al., 2003; Bettis et al., 2003a), but the sources of Great Plains loess are uncertain because neither the Laurentide nor Cordilleran ice sheets entered the headwaters of most rivers in the region.

A better understanding of the sources of Great Plains loess has important implications for paleoclimate studies (i.e., determination of paleowind directions) that can provide critical tests for atmospheric general circulation models (AGCMs). For example, loess paleowind indicators (such as thickness and particle size trends) suggest prevailing northwesterly or westerly paleowind directions (Ruhe, 1983; Muhs and Bettis, 2000; Mason, 2001). In addition, the aerosol component of loess (i.e., material $<10 \mu \mathrm{m}$ ) could have played either a direct role in climate change through radiative transfer or an indirect role in climate change through Fe-fertilization of primary producers in the ocean (Young et al., 1991; Overpeck et al., 1996; Andersen et al., 1998; Mahowald et al., 1999; Kohfeld and Harrison, 2000).

Aleinikoff et al. (1999) used $\mathrm{Pb}$ isotope compositions of detrital K-feldspars and $\mathrm{U}-\mathrm{Pb}$ ages of detrital zircons to show that loess in eastern Colorado was derived from two sources: (1) Proterozoic crystalline rocks of the Colorado province (Tweto, 1987; also known now as the Yavapai province, Whitmeyer and Karlstrom, 2007, and references therein) of the Rocky Mountains via glacial grinding, followed by delivery to, and deflation from, the South Platte River, and (2) epiclastic silt (with a significant volcanic component) derived primarily from the Tertiary White River Group on the Great Plains. In the present study, we have extended our investigations to Nebraska and western Iowa. This area contains the thickest known last-glacial loess deposits (Peoria Loess) in the world. Platte River sediments historically have been considered to be the major source of Peoria Loess in the region (Bryan, 1945; Swineford and Frye, 1951; Reed, 1968; Pye, 1995; Winspear and Pye, 1995). However, the occurrence of loess to the north and south of the Platte would require that paleowinds had been variable and, in fact, opposing. This interpretation seems unlikely given the observation of northwest to southeast decreases in Peoria Loess particle size and thickness (Swinehart et al., 1994a; Mason, 2001; Muhs et al., this volume). Alternatively, it has been suggested that paleowinds were primarily from the west or northwest, but that the Platte River was situated farther to the north during the last glacial period (Winspear and Pye, 1995). Other workers (Lugn, 1939, 1968; Condra et al., 1950; Reed, 1968; Wright, 1970; Mason, 2001; Mason et al., 2003; Miao et al., 2005; Jacobs and Mason, 2007) have suggested that the Nebraska Sand Hills or other nearby dune fields have played a role in the origin of loess in Nebraska.

Isotopic and geochemical analyses have been used to determine loess origins in many studies (cf. Muhs et al., 1999a, 2008; Muhs and Budahn, 2006; Aleinikoff et al., 1999; Sun, 2002a, 2002b; Yokoo et al., 2004), as well as tracing glaciogenic sediments (Bell and Murton, 1995). The goal of our study is to utilize two independent isotopic systems, initial $\mathrm{Pb}$ isotope ratios in $\mathrm{K}$-feldspars and $\mathrm{U}-\mathrm{Pb}$ ages of zircons, to determine the source(s) of late Wisconsin Peoria Loess in Nebraska and western Iowa in order to infer paleowind directions during the last glacial period. In addition, we are interested in establishing the degree of influence of possible nonglaciogenic sources in the mid-continent. In the past, non-glaciogenic loess sources generally 
have not been simulated in atmospheric general climate models (cf. COHMAP members, 1988; Mahowald et al., 1999). However, more recent models have simulated such sources in the Great Plains (Mahowald et al., 2006).

The Platte River has historically been regarded as a likely source for Peoria Loess in Nebraska (Bryan, 1945; Swineford and Frye, 1951; Reed, 1968; Pye, 1995; Winspear and Pye, 1995). This interpretation implies that significant quantities of silt were derived from glacial sources, in turn derived from crystalline rocks in Colorado and Wyoming and transported to the Platte via the South Platte and (or) North Platte Rivers. Glaciation occurred in the headwaters of the North Platte River during the late Wisconsin (Mears, 2001; Madole, 1991a, 1991b). Somewhat larger glaciers occurred in the headwaters of the South Platte River (Madole et al., 1998), but were still of limited extent and confined to valleys. Thus, it seems unlikely that the silt deposited as thick loess deposits in central Nebraska could have been generated by these small glaciers, a point raised more than three decades ago by Flint (1971). An alternative hypothesis is that the silt is non-glacial in origin (Condra et al., 1950; Lugn, 1968; Mason, 2001). Possible non-glacial candidates for the source(s) of Nebraska loess are widespread Tertiary tephra-rich epiclastic sedimentary rocks, for example the White River Group, that crop out in the north-central Great Plains (Condra et al., 1950) or the silt facies of an eolian sand sheet of Pliocene age that occurs beneath the Nebraska Sand Hills (Swinehart et al., 1994b). Another possible source for Peoria Loess is the Nebraska Sand Hills, although early workers were not very specific as to how this dune field played a role in the origin of loess origins (Lugn, 1939, 1968; Condra et al., 1950; Reed, 1968; Wright, 1970). Mason (2001) has emphasized that the importance of the Nebraska Sand Hills for loess genesis was mainly as a "surface of transport," with the ultimate source of the particles from farther upwind.

To determine the likelihood of these possible sources, we collected suites of samples for comparison of isotopic characteristics with Nebraska Peoria Loess. In all cases, we tried to analyze fractions of comparable grain size, usually less than 250-mesh $(<0.063 \mathrm{~mm})$, although for the Nebraska Sand Hills siltsized particles are relatively scarce. Samples were also collected from alluvium in terraces thought to have formed during the last glacial period along the South Platte and Platte Rivers (Swinehart et al., 1994a). These sediments should be representative of silt that was being transported in these rivers at this time. Modern channel silt samples from the North Platte River are available from a previous study.

\section{METHODS}

\section{Field Methods and Sampling Strategy}

Our study combines two sets of isotopic data, $\mathrm{Pb}$ isotope analyses from $\mathrm{K}$-feldspars and $\mathrm{U}-\mathrm{Pb}$ geochronology from detrital zircons, derived from minerals with very different physical and chemical characteristics. K-feldspar is a fairly resistant light mineral (Goldich, 1938) that can, however, be depleted by both mechanical and chemical weathering. Zircon is a robust, refractory mineral that is highly resistant to weathering. Zircon is nearly twice as dense as K-feldspar and thus is more susceptible to mineral concentration. We followed different sampling strategies for each mineral; common, or initial, $\mathrm{Pb}$ analysis (i.e., $\mathrm{Pb}$ incorporated into $\mathrm{K}$-feldspar during crystallization) was determined on bulk samples composed of several milligrams (thousands of grains) of K-feldspar whereas for geochronology ( $\mathrm{U}-\mathrm{Pb}$ ages) individual zircons were dated. By using bulk samples of K-feldspar, we are able to determine the average isotopic characteristics of sources without having to analyze an unrealistic number of individual grains.

Two sampling strategies were used to collect Peoria Loess in Nebraska and western Iowa: (1) samples were collected at depths of $\sim 0.5-1.5 \mathrm{~m}$ below the modern soil profile, or 2-3 $\mathrm{m}$ below the present land surface within the broad, 500-km-long, northeast-southwesttrending belt that encompasses the thickest loess deposits in Nebraska (Swinehart et al., 1994a). The sampling area extends from southwestern Nebraska (on the south side of the Platte River) to northeastern Nebraska (north of the Platte River and south of the Missouri River) and farther east to the Loess Hills of western Iowa, on the east side of the Missouri River (Fig. 2). (2) Samples were collected from a 16-m-thick vertical section of loess at Eustis, Nebraska (south side of the Platte River).

Samples of Peoria Loess used for detrital zircon age determinations were collected at seven localities, including five sites in central Nebraska and two sites in western Iowa (Fig. 2). At Eustis and Devils Den, Nebraska, on the south and north sides of the Platte River, respectively, two samples (near the top and bottom of Peoria Loess at each section) were collected in an attempt to determine if zircon age distribution patterns show changes in source areas over time. In addition, we collected seven samples of potential source materials (Fig. 2). These include three samples of the White River Group (or sediment derived from it) from northeastern Colorado, western Nebraska, and southern South Dakota, two samples from Platte River alluvium from Wisconsin-age terraces, one sample of
Pliocene silt from below Holocene eolian sand of the Sand Hills region of western Nebraska, and one sample of glacial till from the terminal moraine of the James Lobe in South Dakota. With the exception of grains from the White River Group, most of the zircons samples have typical detrital morphologies. Most populations of zircon from Peoria Loess are composed of grains with a wide variety of colors (e.g., red, orange, tan, brown, and colorless grains) and external form (spherical to lozenge-shape). Most grains are rounded, and have frosted, pitted surfaces (Fig. 3A). In contrast, zircons from the White River Group contain many euhedral, prismatic, unabraded grains (Fig. 3B).

\section{Laboratory Methods}

K-feldspars from loess and potential sources were extracted by flotation in sodium polytungstate and purified using a magnetic separator. $\mathrm{K}$-feldspars separates were dissolved in concentrated $\mathrm{HF}$ and $\mathrm{HNO}_{3}$ in screw-top containers on a hot plate at $\sim 200{ }^{\circ} \mathrm{C}$. $\mathrm{Pb}$ was extracted using the method developed by Krogh (1973). $\mathrm{Pb}$ isotope compositions were measured on a VG Isomass 54E thermal ionization mass spectrometer. Isotopic data are plotted using the Isoplot program of Ludwig (2003) on standard 3.0 ${ }^{206} \mathrm{~Pb} /{ }^{204} \mathrm{~Pb}-{ }^{207} \mathrm{~Pb} /{ }^{04} \mathrm{~Pb}$ plots.

Zircons from loess and potential sources were extracted by pulverizing, processing over a Wilfley table, and purification using a magnetic separator and methylene iodide. U-Pb ages of zircons were determined by analysis on a sensitive high resolution ion microprobe (SHRIMP; either SHRIMP II at the Research School of Earth Sciences, Australian National University, or the U.S. Geological Survey [USGS]/Stanford SHRIMP-RG at Stanford University) following methods described in Williams (1998). Isotopic data were collected using a primary oxygen ion beam focused to a 20-30 $\mu \mathrm{m}$ analytical spot and cycling through the mass stations four times. SHRIMP data were reduced using the Squid program of Ludwig (2001). Relative probability plots (Ludwig, 2003) are used to compare age distributions of samples.

About 50 detrital zircons from each sample were analyzed on SHRIMP. The mount was prepared by sprinkling grains (i.e., no handpicking) onto a piece of double-stick tape prior to embedding in epoxy. However, despite our efforts to avoid biasing the sample, a number of factors contribute to the selection of grains for analysis, all of which influence the data set to some degree. These include both natural and laboratory processes. For example, zircons in a sediment can be nonrepresentative of the provenance(s) because of: (1) varying zircon 
$104^{\circ} \mathrm{W}$

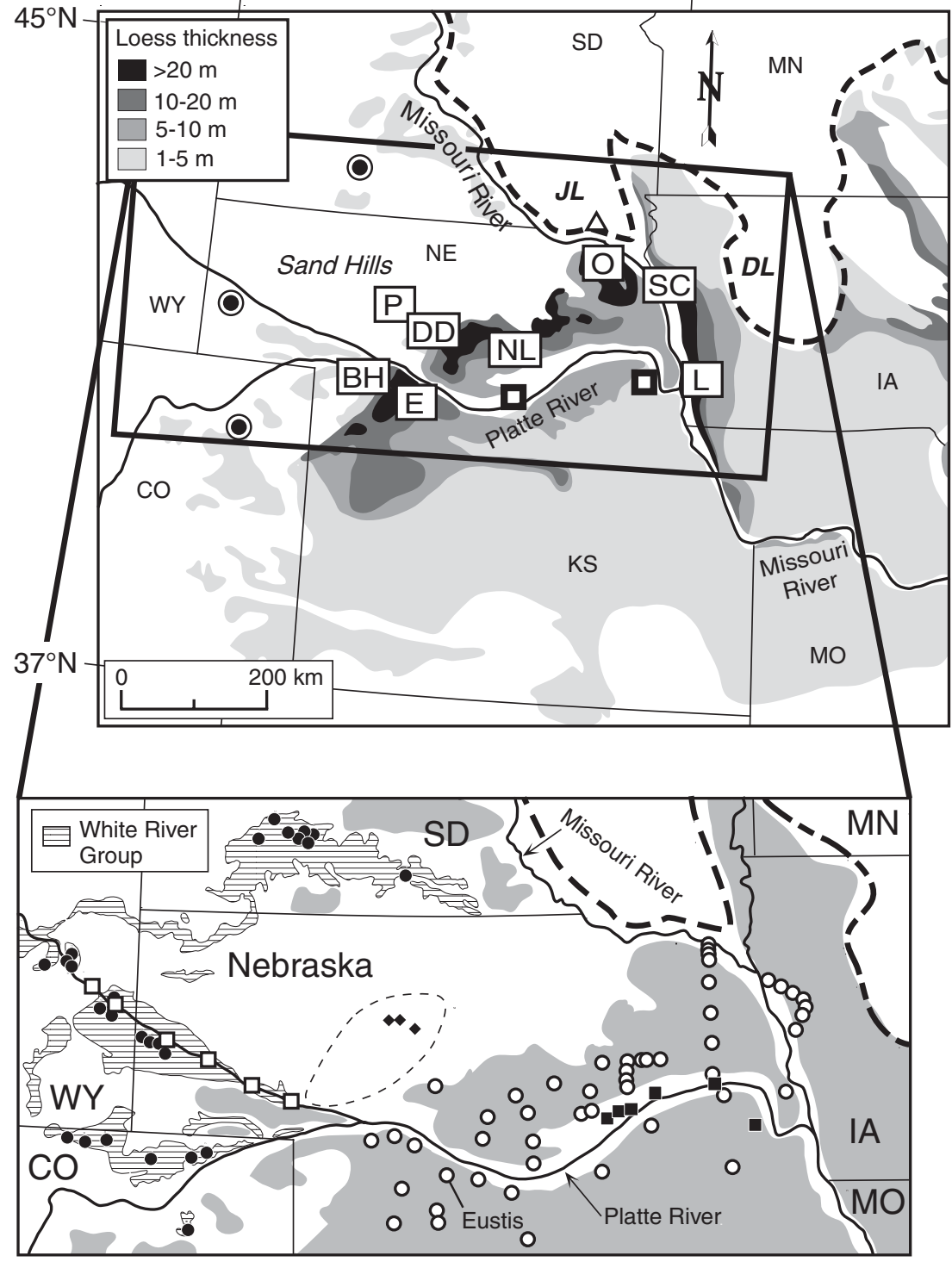

Figure 2. Map showing locations of detrital zircon samples used in this study. Lettered boxes are Peoria Loess samples. Abbreviations: BH (Bignell Hill), DD (Devils Den), E (Eustis), NL (North Loup), $P$ (Pliocene sand sheet), SC (Sioux City), L (Loveland). Squares are Platte River alluvial terrace samples; dots are White River Group samples; triangle is till sample. $J L$-James Lobe; $D L$-Des Moines Lobe. Heavy dashed line shows limit of Laurentide Ice Sheet. Inset: locations of K-feldspar samples used in this study. Filled dots are White River Group; open dots are Peoria Loess; filled squares are Platte River Wisconsin terrace alluvial samples; open squares are North Platte River channel silt samples; filled diamonds are Pliocene sand sheet samples (five samples from three localities). Gray shaded areas are loess. Thin dashed line shows approximate extent of Pliocene sediments (mostly buried) (Myers, 1993; Swinehart, 2007, personal commun.).
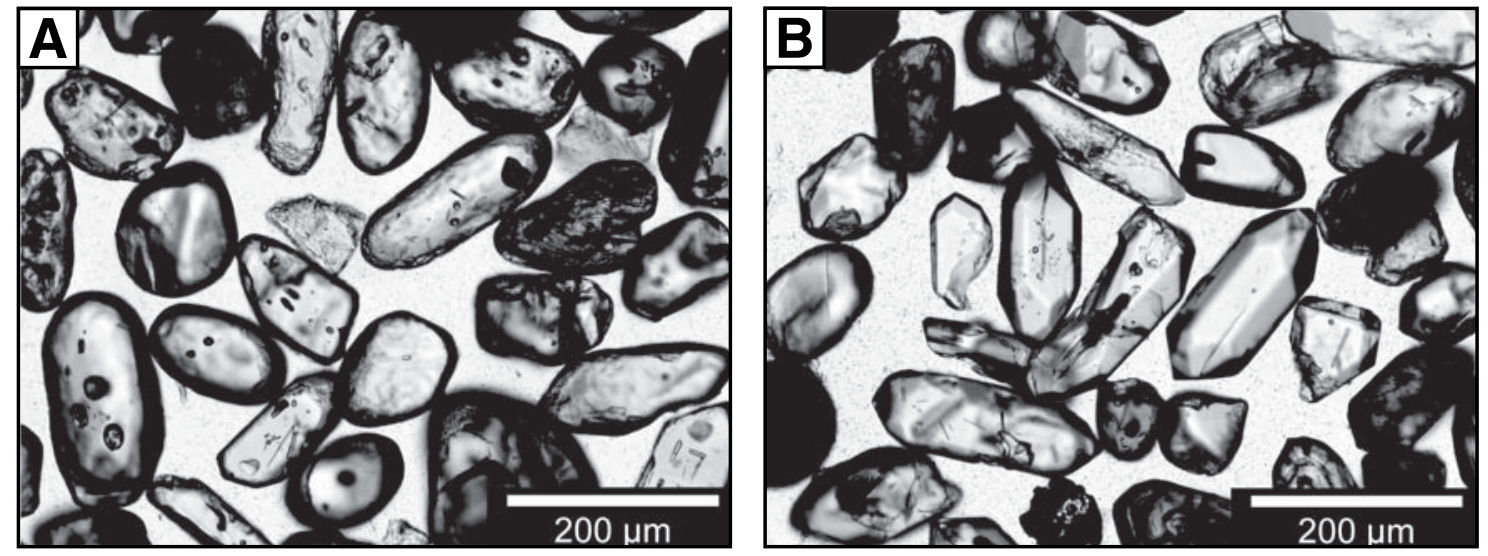

Figure 3. Transmitted light photomicrographs of zircon dated by sensitive high resolution ion microprobe (SHRIMP) analysis. (A) Detrital zircons from loess sample NE-516 (North Loup, Nebraska locality). (B) Zircons from White River Group sample BADL-96-05 (Badlands National Park, South Dakota locality). 
size and concentration in the different source rocks, (2) different mechanical processes (such as abrasion) encountered by sediments following different transport paths, and (3) degree of metamictization of zircons, a function of age and uranium and thorium content (metamict zircons are more easily destroyed than pristine zircons). Laboratory biases affecting the sample population include: (1) grain size (analysis by SHRIMP is much easier using coarser grains), (2) mount preparation (sprinkling of different grain shapes may result in local concentrations related to morphology), and (3) analysis of poorly preserved or high-U grains whose ages are discordant and therefore excluded from relative probability curve plots. In addition to the bulk zircon samples, prismatic, euhedral, colorless, pristine (relatively unabraded) zircons of presumed young age were handpicked in some samples in order to determine if the loess contained a White River Group (or other Tertiary) component.

Our field sampling procedure involved collection of only a few samples, from which a limited number of zircons were dated by SHRIMP. A more rigorous statistical processing of the data sets would require collection of many more samples and analysis of many more zircons from each sample. Thus, only the presence of a particular detrital age population is used for comparison of units for the evaluation of potential sources of Peoria Loess. Apparent absence of an age group within the detrital population is not necessarily diagnostic, but may simply be a sampling bias (either natural or laboratory). However, in the case of handpicked euhedral grains, lack of a specific age group may be significant in discerning provenance(s). With these limitations in mind, age distribution plots are used as general guides to aid in determining the provenance(s) of Peoria Loess of Nebraska and western Iowa.

For each sample, between $\sim 40$ and 55 grains were dated, within the requirements discussed by Andersen (2005). Major age populations (composed of many analyses) are the basis for comparison of Peoria Loess and potential sources. Of particular significance is the presence of 1.0-1.7 Ga and 15-35 Ma populations. Minor age populations (i.e., age peaks generated by data from a single grain) are of limited use in this study. Thus, we are more interested in comparing major age groups (i.e., the so-called "qualitative strategy" of Fedo et al., 2003), rather than attempting to discern all age populations. In this sense, and because of limited instrument time for analysis, the statistics of detrital zircon populations (Dodson et al., 1988; Vermeesch, 2004; Andersen, 2005) were not considered for this study.
In relative probability (age distribution) plots, we use the ${ }^{207} \mathrm{~Pb} /{ }^{206} \mathrm{~Pb}$ age for zircons older than $1.0 \mathrm{Ga}$, whereas for younger zircons we use the ${ }^{206} \mathrm{~Pb} /{ }^{238} \mathrm{U}$ age. $\mathrm{A}{ }^{207} \mathrm{~Pb} /{ }^{206} \mathrm{~Pb}$ age is considered appropriate for inclusion in the data set used for calculation of a relative probability curve if the accompanying ${ }^{206} \mathrm{~Pb} /{ }^{238} \mathrm{U}$ age is less than $10 \%$ discordant. For ages between ca. 0.6 and $1.0 \mathrm{Ga}$, degree of discordance was assessed on a sampleby-sample basis, depending on the magnitude of uncertainty in ${ }^{207} \mathrm{~Pb} /{ }^{206} \mathrm{~Pb}$ age. Zircon ages in this range that are less than $10 \%$ discordant almost always have ${ }^{206} \mathrm{~Pb} /{ }^{338} \mathrm{U}$ ages with significantly lower uncertainty than the accompanying ${ }^{207} \mathrm{~Pb} /{ }^{06} \mathrm{~Pb}$ ages. However, because low-U zircons yield very imprecise ${ }^{207} \mathrm{~Pb} /{ }^{206} \mathrm{~Pb}$ ages, it is sometimes difficult to compare ${ }^{207} \mathrm{~Pb} /{ }^{206} \mathrm{~Pb}$ and ${ }^{206} \mathrm{~Pb} /{ }^{238} \mathrm{U}$ ages. For ages younger than ca. $0.6 \mathrm{Ga}$, uncertainties in ${ }^{207} \mathrm{~Pb} /{ }^{206} \mathrm{~Pb}$ ages usually are very large (because of the very small amount of ${ }^{207} \mathrm{~Pb}$ generated by decay of ${ }^{235} \mathrm{U}$ ), and are therefore useless for calculating discordancy. In our study, the most important young ages for understanding sources of loess deposition are in the range of ca. 5 to $150 \mathrm{Ma}$ (mostly ca. 15 to $35 \mathrm{Ma})$. We assume that these ${ }^{206} \mathrm{~Pb} /{ }^{238} \mathrm{U}$ ages are concordant because the analyzed grains are pristine, relatively fresh, and not metamict. This assumption is validated when there is a grouping of several ${ }^{206} \mathrm{~Pb} /{ }^{238} \mathrm{U}$ ages. $\mathrm{U}-\mathrm{Pb}$ age data for zircons from all samples are shown as paired relative probability plots, recording age distributions within intervals of 0 to 100 (or 200) Ma and 200 to 3000 (or 3300) Ma.

\section{RESULTS}

\section{Pb Isotope Ratios in K-Feldspars}

\section{Potential Sources of Loess}

$\mathrm{Pb}$ isotope data (Table $\left.\mathrm{DR} 1^{1}\right)$ from South Platte River silt-sized K-feldspars (Aleinikoff et al., 1999) plot slightly below the Stacey and Kramers (1975) $\mathrm{Pb}$ isotope evolution curve, with a broad range in ${ }^{206} \mathrm{~Pb} /{ }^{204} \mathrm{~Pb}$ of $\sim 17.5$ to 18.7 , whereas $\mathrm{Pb}$ isotope data from North Platte River silt-sized K-feldspar grains plot significantly above the curve (Fig. 4A). These results are not surprising and likely are due to the different ages of rocks in the headwaters of the rivers. Sediments in the South Platte River are derived primarily (either directly or via recycling through Paleozoic sedimentary rocks) from Paleoproterozoic and Mesoproterozoic

${ }^{1}$ GSA Data Repository Item 2008166, U-Pb ages of detrital zircons and $\mathrm{Pb}$ isotope compositions of $\mathrm{K}$-feldspars in Peoria Loess and sources, is available at www.geosociety.org/pubs/ft2008.htm. Requests may also be sent to editing@ geosociety.org. crystalline basement rocks of the Colorado province, whereas the provenances of North Platte River sediments predominantly are Archean and Paleoproterozoic crystalline basement rocks of the Wyoming province. Both rivers have variable sedimentary components derived from Tertiary volcanic rocks, mainly the Oligocene White River Group. Silt-sized K-feldspars from Wisconsin terrace sediments of the Platte River plot between the data fields for K-feldspar from the North and South Platte Rivers, consistent with the expected mixing of the two tributaries.

K-feldspars from the Oligocene White River Group are very radiogenic (Fig. 4B). Only $\mathrm{Pb}$ isotope ratios with the lowest values overlap the field of $\mathrm{Pb}$ isotope data from Platte River terrace samples. In Figure 4B, Pb isotope data from the White River Group are subdivided by geographic location; samples from Colorado, Nebraska, and Wyoming are grouped because they occur relatively close to each other and are quite distant from the South Dakota samples (Fig. 2). $\mathrm{Pb}$ isotope data from White River Group-derived sediments from South Dakota plot in a limited field within the much larger array formed by data from the other locations.

$\mathrm{Pb}$ isotope data from silt-sized K-feldspars from samples of the Pliocene sand sheet beneath the Nebraska Sand Hills are also relatively radiogenic, plotting in a field with a broad range of ${ }^{206} \mathrm{~Pb} /{ }^{204} \mathrm{~Pb}$ (18.4-19.2). In contrast, sand-size grains from the Pliocene sand sheet are significantly less radiogenic $\left({ }^{206} \mathrm{~Pb} /{ }^{204} \mathrm{~Pb}\right.$ of $16.8-17.5$; Fig. 4A), indicating that the two grain sizes of $\mathrm{K}$-feldspar were derived from different sources. We interpret these data to indicate that the silt fractions contain relatively high proportions of young grains (Fig. 4B), whereas the sand fractions have relatively high proportions of older (pre-Paleozoic) grains. The isotopic data from silt fractions suggest that these K-feldspars were derived from at least two sources, perhaps the White River Group (high ${ }^{206} \mathrm{~Pb} /{ }^{204} \mathrm{~Pb}$ end member) and Platte River sediments (low ${ }^{206} \mathrm{~Pb} /{ }^{204} \mathrm{~Pb}$ end member). The location of the field of sandsized K-feldspars above the Stacey and Kramers (1975) average growth curve (Fig. 4A) implies a significant Archean component, as has also been determined for sediment in the North Platte River, which drains the Archean Wyoming province.

Another possible source of silt in the region is the Missouri River, which carried late Wisconsin meltwater from the margin of the Laurentide Ice Sheet (including the James Lobe of southeastern South Dakota) (Fig. 2). Unfortunately, no significant areas of late Wisconsin outwash terraces along the Missouri have been identified in the literature (cf. Swinehart et al., 1994a) and thus we could not sample glaciogenic material 

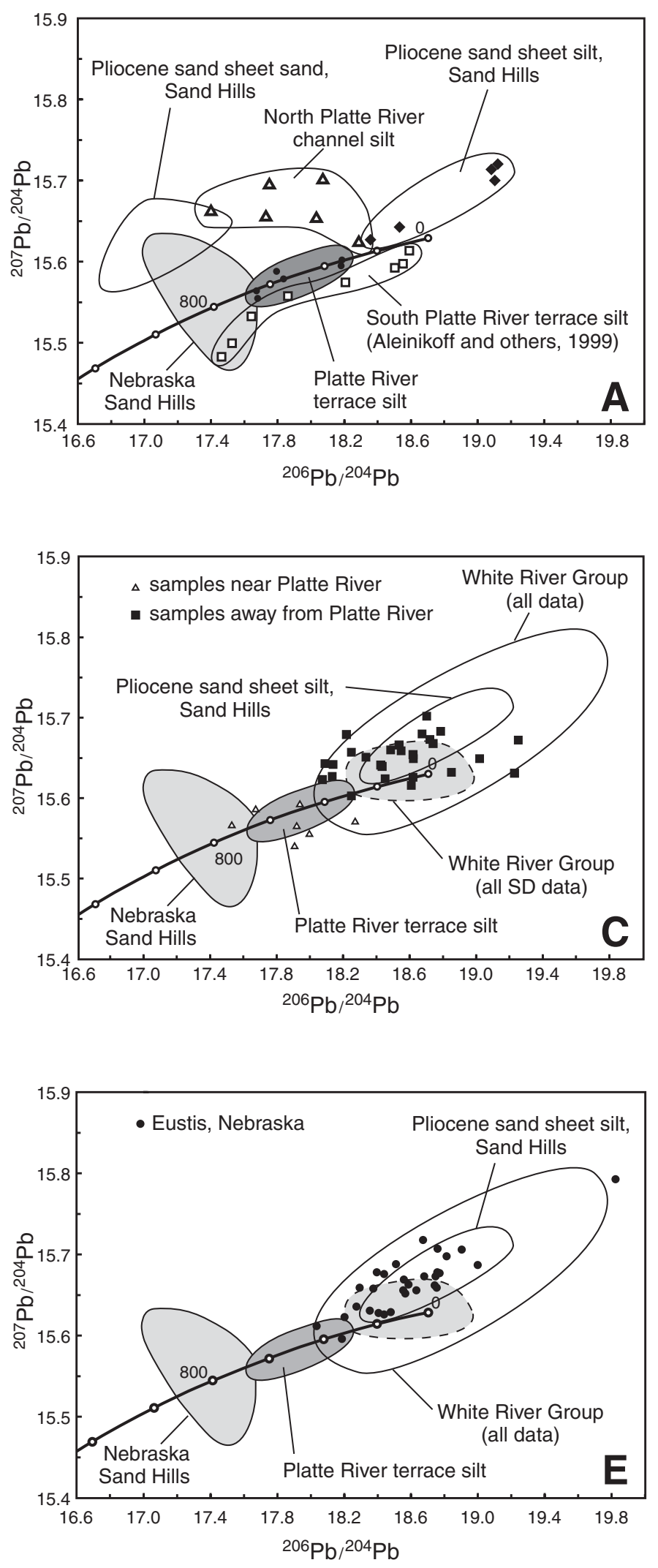
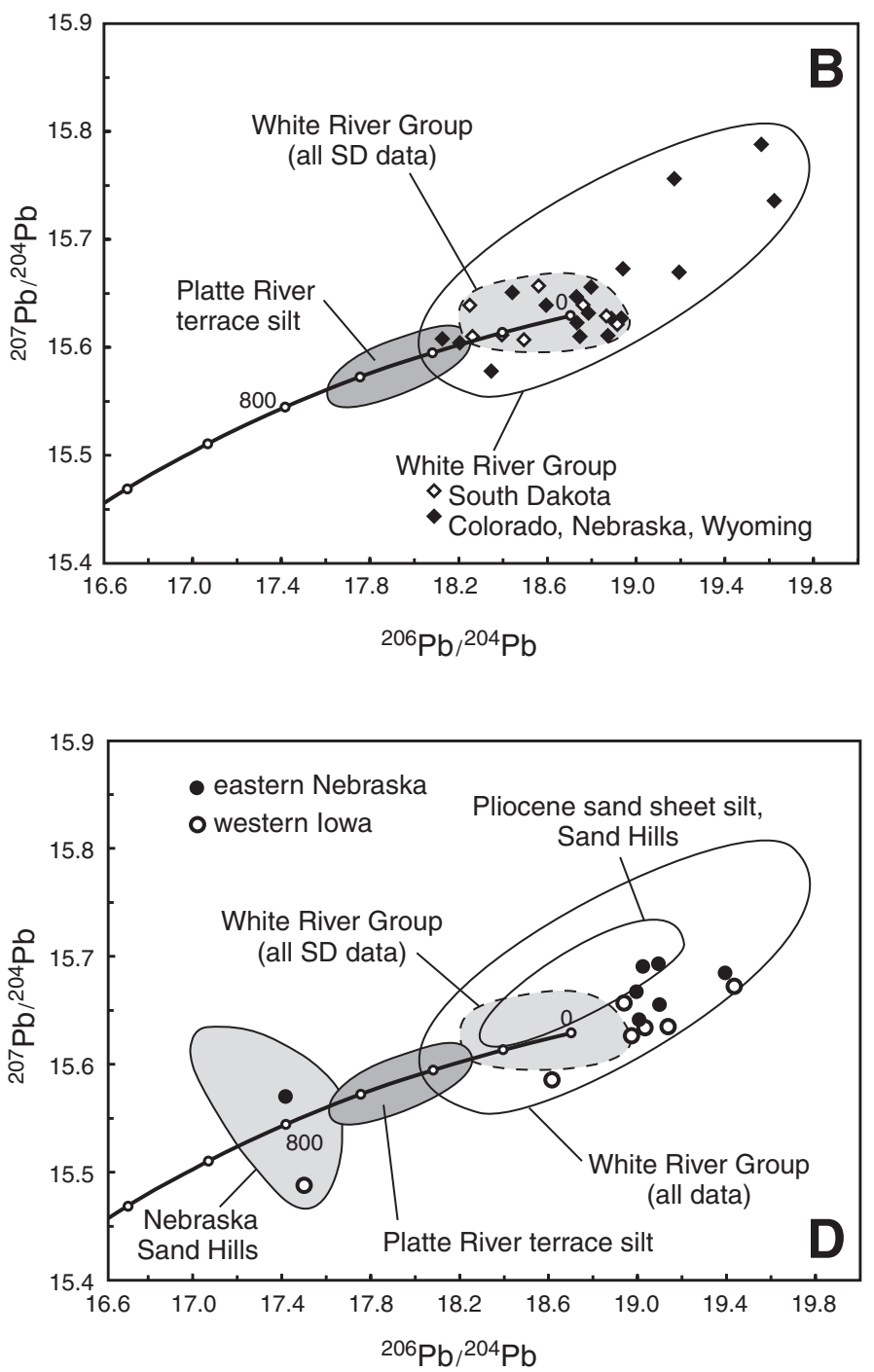

Figure 4. Plots of K-feldspar $\mathrm{Pb}$ isotope data from potential sources and Nebraska loess. In this and subsequent plots, $\mathrm{Pb}$ isotope evolution curve (showing the average ${ }^{206} \mathrm{~Pb} /{ }^{204} \mathrm{~Pb}$ of crust through time) is from Stacey and Kramers (1975). (A) Data from river samples, plus eolian deposits of the Nebraska Sand Hills and the Pliocene sand sheet. Fields for Nebraska Sand Hills and Pliocene sand sheet sand from J.N. Aleinikoff (unpublished data). (B) Data from samples of White River Group. Lightly shaded field encompasses all data from South Dakota (SD) samples. (C) Data from upper Peoria Loess of central Nebraska. Triangles are samples with relatively low $\mathrm{Pb}$ isotope ratios, mostly located near the Platte River (see Fig. 5). All other samples in central Nebraska are shown as squares. (D) Data from upper Peoria Loess of northeastern Nebraska and western Iowa. (E) Data from vertical section of Peoria Loess at Eustis, Nebraska. 
in this region. Modern sediments in the river cannot be used as proxies for late Wisconsin silt because loess is currently being recycled into the Missouri along much of its course through the upper Great Plains. Therefore, we collected other sediments for U-Pb detrital zircon ages from the area: (1) a sample of James Lobe till from just north of the Missouri River, and (2) a sample of Peoria Loess from a locality near Sioux City Iowa, just south of the Missouri (Fig. 2). The Sioux City, Iowa, locality is situated where the Missouri River is likely to have been the major loess source (see discussion in Muhs et al., 2008).

\section{Peoria Loess}

$\mathrm{K}$-feldspar grains from Peoria Loess in Nebraska and western Iowa contain a wide range of $\mathrm{Pb}$ isotope compositions $\left({ }^{206} \mathrm{~Pb} /{ }^{204} \mathrm{~Pb}\right.$ range of $\sim 17.5$ to 19.4 ). Within this broad data array, three subgroups are discernable. Three samples from southwestern Nebraska (two samples collected near the Platte River and one sample from south-central Nebraska, Fig. 5) have distinctly lower $\mathrm{Pb}$ isotope ratios $\left({ }^{206} \mathrm{~Pb} /{ }^{204} \mathrm{~Pb}\right.$ of $\sim 17.5-18.0$; Fig. $\left.4 \mathrm{C}\right)$. In contrast, 28 samples from central Nebraska (from both sides of the Platte River, Fig. 5) have more radiogenic $\mathrm{Pb}$ isotope ratios $\left({ }^{206} \mathrm{~Pb} /{ }^{204} \mathrm{~Pb}\right.$ of 18.0-19.2; Fig. 4C). Samples from northeastern Nebraska and western Iowa (Fig. 5) mostly have $\mathrm{Pb}$ isotope compositions that partially overlap with the data from loess in central Nebraska but also extend to even more radiogenic values (11 of 14 samples with ${ }^{206} \mathrm{~Pb} /{ }^{204} \mathrm{~Pb}$ of 18.9-19.5; Fig. 4D). One sample each from eastern Nebraska and western Iowa have distinctly lower ${ }^{206} \mathrm{~Pb} /{ }^{204} \mathrm{~Pb}$ ratios (Fig. 4D).

The groups of K-feldspar samples, subdivided on the basis of $\mathrm{Pb}$ isotope composition and geographic location, can be directly related to different sources (Figs. 4D and 5). K-feldspars from western Nebraska and sites adjacent to the Platte River in central Nebraska are interpreted to have been derived primarily by deflation of silt from Platte River deposits. K-feldspars from the vast expanse of thick Peoria Loess throughout central Nebraska were derived primarily from silt of the White River Group. The most likely process by which the silt was delivered to central Nebraska is via deflation and eolian transport from White River Group rocks in South Dakota, probably through the Sand Hills (Mason, 2001). Loess in central Nebraska may also have been derived in part from silt in the Pliocene sand sheet (Fig. 4C). Although the quantity of silt currently within the Pliocene sand sheet may be low (Swinehart and Diffendal, 1990), it is possible that a significant percentage of the original silt component was removed and deposited as

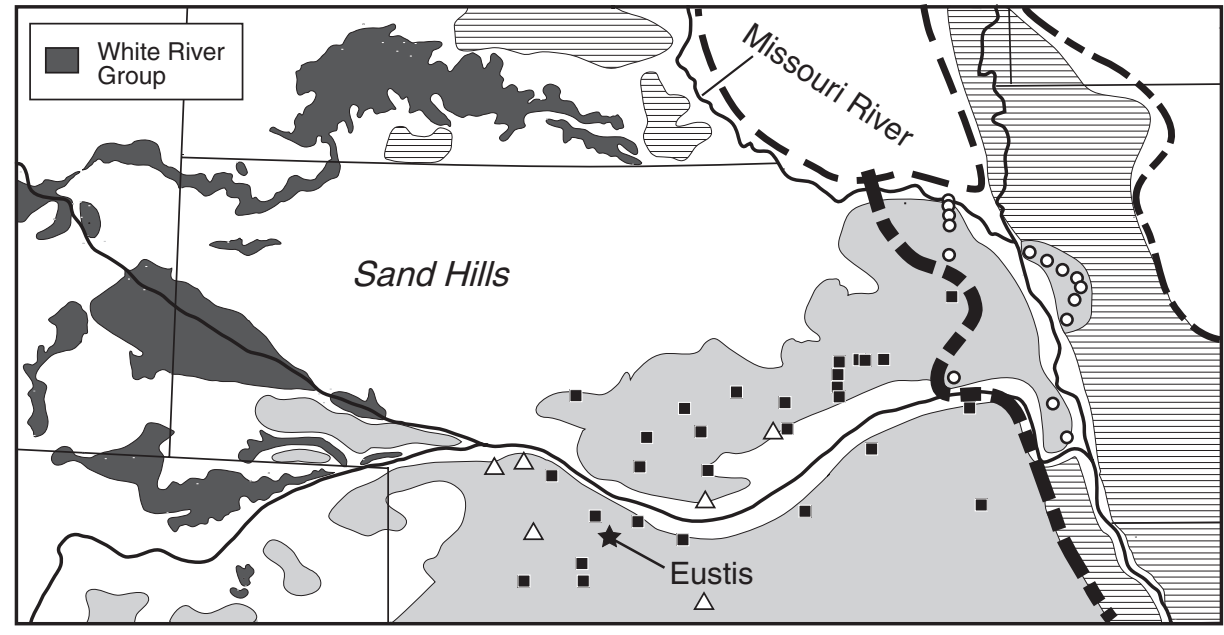

Figure 5. Subdivision of Peoria Loess in Nebraska, northeastern Colorado, and western Iowa on the basis of interpretation of K-feldspar $\mathrm{Pb}$ isotope data. Open triangles are samples derived from South Platte River or Platte River silt; filled squares are samples derived from White River Group; open circles are samples derived from Missouri River silt. Gray shaded areas are loess for which origins have been interpreted. Regions delineated by horizontal lines are areas of loess of unknown origin. Heavy dashed line separates loess of glaciogenic (to the east) and non-glaciogenic (to the west) origins. Star labeled Eustis is location of analyzed vertical section of Peoria Loess (see Fig. 6).

loess (Mason, 2001). Thus, it is unclear to what degree the Pliocene sand sheet provided material for the Peoria Loess. In any case, the Pb isotope data suggest that silt in both Peoria Loess and the Pliocene sand sheet deposits were ultimately derived from the White River Group.

$\mathrm{Pb}$ isotope compositions in $\mathrm{K}$-feldspars from loess samples in eastern Nebraska and western Iowa do not match data sets from either the Platte River or the White River Group. We suspect that the source of this loess is glaciogenic silt deflated from the Missouri River valley. However, this interpretation is tentative because we were unable to obtain any samples of Missouri River glaciofluvial silt of unequivocal late Wisconsin age for comparison. As we discuss later, however, $\mathrm{U}-\mathrm{Pb}$ ages of detrital zircons support this preliminary interpretation.

\section{Pb Isotope Compositions of Loess over Time}

$\mathrm{Pb}$ isotope compositions were measured on K-feldspars extracted from Peoria Loess samples collected from a vertical section at Eustis, Nebraska (to the south of the Platte River) in order to assess the possibility that sources changed with time. This loess was sampled at $0.5 \mathrm{~m}$ intervals over a total thickness of $\sim 16 \mathrm{~m}$. On the basis of optically stimulated luminescence (OSL) dating, loess at Eustis was deposited between $\sim 22,000$ and 14,000 cal years ago (Roberts et al., 2003). Pb isotope data from K-feldspars for all samples from the
Eustis section are highly radiogenic (Fig. 6), plotting within the broadest field of the White River Group (i.e., isotopic data from samples from Colorado, Wyoming, Nebraska, and South Dakota) (Fig. 4E). There is a significant spread in the data $\left({ }^{206} \mathrm{~Pb} /{ }^{204} \mathrm{~Pb}\right.$ of $\sim 18.1-19.0$, plus one outlier at 19.8). We suggest that Peoria Loess from Eustis was primarily derived from the White River Group, consistent with other locations in central Nebraska.

Within the vertical section of loess at Eustis there is significant variation of $\mathrm{Pb}$ isotope compositions in K-feldspar grains. As shown in Figure 6, nearly all of the K-feldspar samples from Peoria Loess (with the exception of one highly radiogenic sample at a depth of $15 \mathrm{~m}$ ) have ${ }^{206} \mathrm{~Pb} /{ }^{204} \mathrm{~Pb}$ ratios that are similar to isotopic ratios measured from $\mathrm{K}$-feldspars from the White River Group. However, over a span of $\sim 4000 \mathrm{yr}$, there appears to be a general, but small, decrease ( 18.8-18.3, but with much scatter) in ${ }^{206} \mathrm{~Pb} /{ }^{204} \mathrm{~Pb}$ upsection (Fig. 6). This change in isotopic ratio may be due to a greater proportion of Platte River-derived silt in the stratigraphically higher, younger loess. From $\mathrm{K}$-feldspar isotopic data alone, we are unable to determine if this change in $\mathrm{Pb}$ isotope ratio is caused by an increased flux of silt deflated from the Platte, or a decrease in the eolian component deflated from the White River Group. However, we suspect it is more likely the former, as the mass accumulation rate increases upsection at 


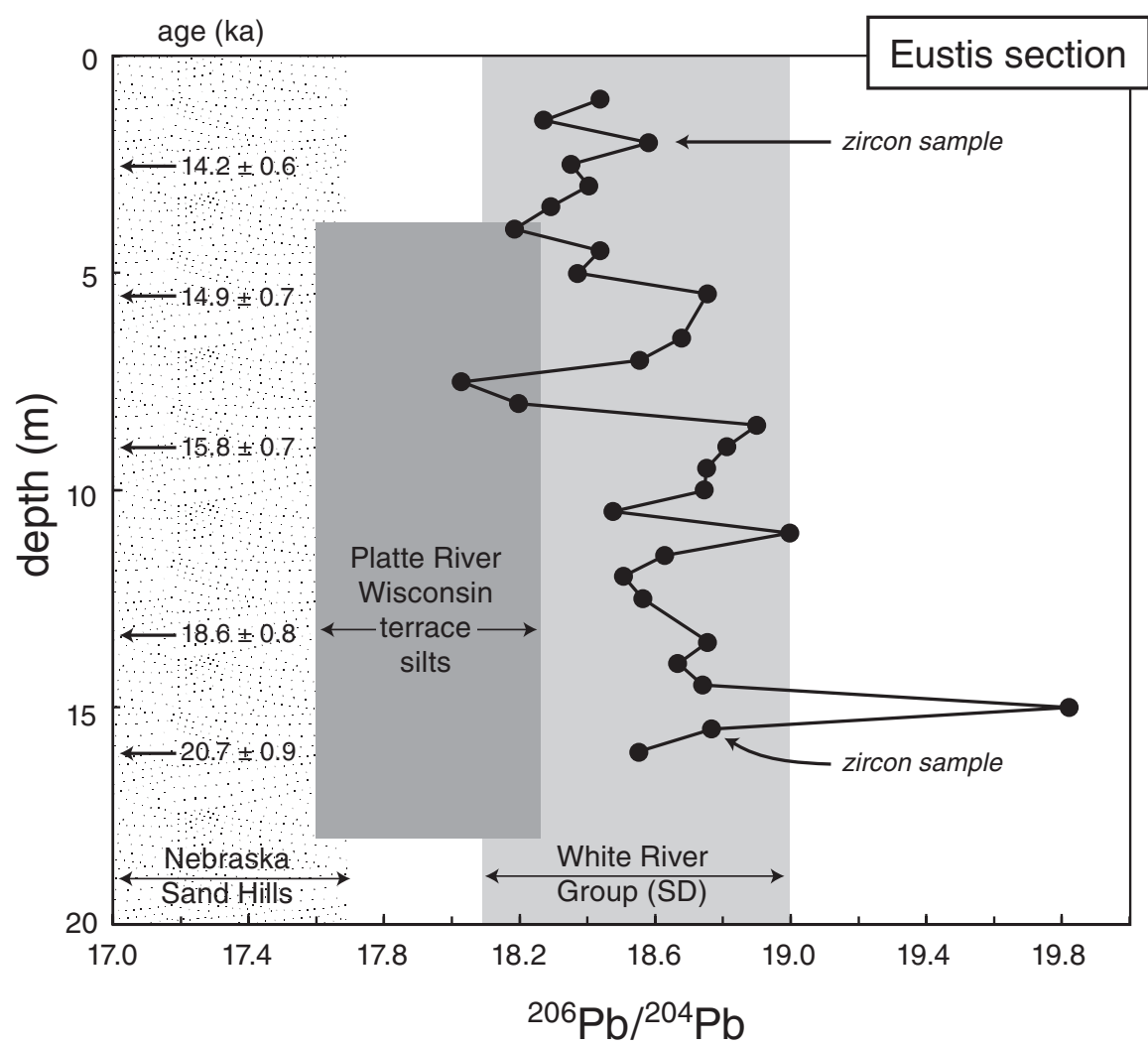

Figure $6 .{ }^{206} \mathrm{~Pb} /{ }^{204} \mathrm{~Pb}$ as a function of burial depth at vertical section of Peoria Loess at Eustis, Nebraska. See Muhs et al. (2008) for particle size analyses of samples from this section. Ages shown in the Eustis section are optically stimulated luminescence (OSL) dates in calendar ka \pm 1 sigma (Roberts et al., 2003).

Eustis (Roberts et al., 2003) despite no systematic trend in particle size (Muhs et al., 2008).

In summary, $\mathrm{Pb}$ isotope compositions of K-feldspars from samples of Peoria Loess from the vertical section at Eustis, Nebraska, indicate that the loess was derived from multiple sources whose relative contributions varied systematically with time, although the White River Group appears to be the dominant source overall. We propose that the general trend of variation in $\mathrm{Pb}$ isotope composition reflects changing sediment availability from different sources that, in turn, are due to changing climatic conditions (discussed in detail below).

\section{U-Pb Ages of Detrital Zircons}

$\mathrm{U}-\mathrm{Pb}$ ages of detrital zircons from samples of Peoria Loess and potential sources provide an additional method for determining the origin of the loess in Nebraska and western Iowa. Ages obtained from zircons represent an independent data set from $\mathrm{Pb}$ isotope analyses of $\mathrm{K}$-feldspars and thus serve as an important test of conclusions based on the $\mathrm{Pb}$ isotope data. As previously shown by Aleinikoff et al. (1999), a combination of the two data sets limits the range of possible interpretations and results in more robust conclusions than would be possible when considering each data set alone.

We divide the following discussion of results of zircon $\mathrm{U}-\mathrm{Pb}$ geochronology from both loess samples and potential sources into two sections on the basis of results from the $\mathrm{Pb}$ isotope data: (1) central Nebraska and (2) northeastern Nebraska and western Iowa. In central Nebraska, three samples each were collected from north and south of the Platte River. At both Devils Den (north of the Platte River) and Eustis (south of the Platte River) (Fig. 2), we collected samples from both the upper and lower portions of Peoria Loess. At the North Loup and Bignell Hill localities, we present data from upper Peoria Loess only.

\section{Potential Sources of Loess in Central Nebraska}

The previously identified possible loess sources (White River Group, Platte River, and Pliocene sand sheet east of the Nebraska Sand Hills) for Peoria Loess were sampled at six localities for detrital zircons. Samples of the White River Group were collected in northeastern
Colorado ( $\sim 45 \mathrm{~km}$ east-southeast of Fort Morgan; sample WR-1), western Nebraska ( 9 km west-southwest of Scottsbluff; sample WY-201), and South Dakota (in western Badlands National Park, $\sim 15 \mathrm{~km}$ northeast of Scenic; sample BADL-96-05). Two samples were collected from late Wisconsin terrace alluvium (mapped by Swinehart et al., 1994a) of the Platte River; these localities are $\sim 35 \mathrm{~km}$ due west of Omaha (sample NE-601) and just southwest of Grand Island (sample NE-608). The Pliocene sand sheet sample (NE-332) was collected along the Middle Loup River in Thomas County, Nebraska, between Seneca and Thedford, where this unit is exposed in cutbanks (Swinehart et al., 1994b).

Relative probability curves for the three samples of White River Group have similarities, as expected (Fig. 7). Samples from South Dakota and Colorado have a major zircon population at ca. 32-36 Ma (age of eruption that generated the airfall tephra component of the White River Group, Zielinski and Naeser, 1977), plus distinct age groups in the Proterozoic at ca. 1.0-1.1, 1.4-1.5, and 1.6-1.8 Ga (Table DR2 [see footnote 1]; Fig. 7A). The Proterozoic age groups correspond to the ages of crystalline rocks in the mountains of the Colorado province (Van Schmus et al., 1993). The South Dakota sample also contains several grains of Archean age (ca. 2.5-2.9 Ga).

One potentially complicating factor in trying to distinguish possible sources is that White River Group rocks in northeastern Colorado and western Nebraska crop out adjacent to the South Platte and North Platte Rivers, respectively. Thus, material from the White River Group may be present as a component of Platte River silt (Fig. 7B). Zircon ages support this inference. Alluvium in late Wisconsin terraces of the Platte River has distinct zircon populations at 32-36 Ma, three Proterozoic age groups $(1.0-1.1,1.4-1.5$, and $1.65-1.75 \mathrm{Ga})$ representative of crystalline basement rocks of the Colorado province, and a few late Archean $(2.6 \mathrm{Ga})$ grains. Detrital zircons of silt size from the Pliocene sand sheet have an age distribution similar to zircons from the Platte River terrace samples (Fig. 7B), including a major peak at ca. 25-40 Ma, plus Mesoproterozoic and Archean grains. The presence of an Archean component was suggested by the relatively high ${ }^{207} \mathrm{~Pb} /{ }^{204} \mathrm{~Pb}$ values from $\mathrm{K}$-feldspar samples, plotting significantly above the Stacey and Kramers (1975) average growth curve.

Nevertheless, several features can be used to distinguish data sets of Platte River and Pliocene sand sheet samples from samples of the White River Group. For example, the Platte River terrace alluvium and Pliocene sand sheet samples contain a few grains younger than 

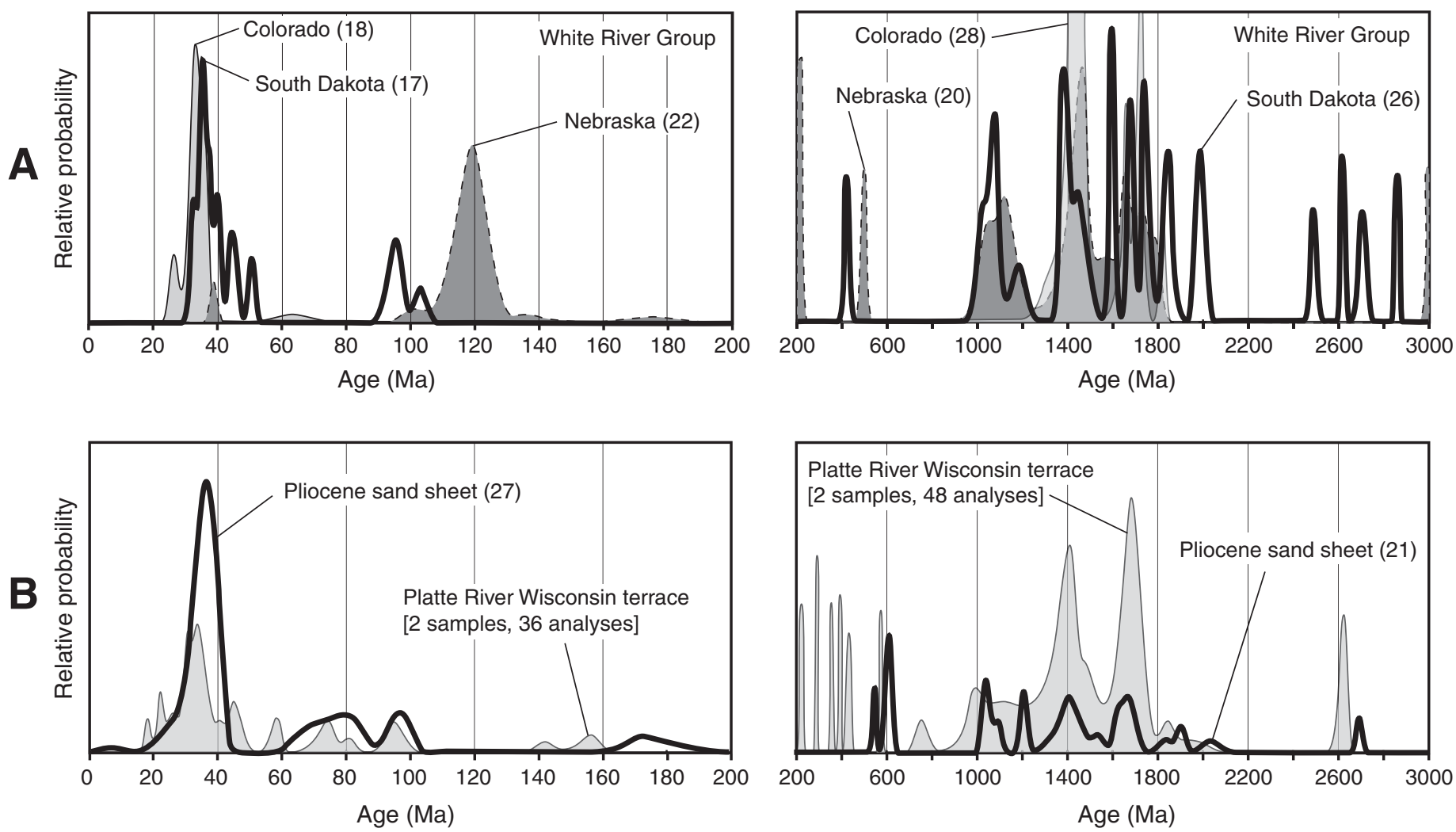

Figure 7. Relative probability curves (a representation of the summation of a set of age data with Gaussian error distributions) showing age distributions for samples of detrital zircons from potential sources of loess. (A) White River Group. Light gray shaded curve is WR-1 (from Colorado), dark gray shaded curve is WY-201 (from Nebraska), unshaded heavy curve is BADL-96-05 (from South Dakota). (B) Platte River Wisconsin terrace samples (data from samples NE-601 and NE-608 are combined) and Pliocene sand sheet (sample NE-332). For this and subsequent figures, values in parentheses are the number of analyses used to generate each curve. See Figure 2 for location of detrital zircon samples.

$28 \mathrm{Ma}$ (Table DR2). These grains probably were derived from tephras in the Arikaree (19-28 Ma) or Ogallala (5-19 Ma) Groups. Also, the sample of White River Group sediment from South Dakota contains a wide range of Proterozoic and Archean age groups, whereas the Platte River terrace and Pliocene sand sheet samples are dominated by zircons from the three main Proterozoic age groups of the Colorado province, plus a few grains between 200 and $600 \mathrm{Ma}$. The occurrence of Tertiary zircons in samples from the Platte River terraces cannot be ascribed to a single or definitive process. These grains could have been transported and deposited by the South or North Platte Rivers, both of which drain terrain composed of Tertiary rocks, or they could have been deposited via eolian erosion and deflation from Tertiary rocks upwind in South Dakota and Nebraska.

\section{Detrital Zircon Ages in Peoria Loess of Central Nebraska}

Six samples of late Wisconsin loess in central Nebraska were processed for detrital zircon $\mathrm{U}-\mathrm{Pb}$ geochronology. These include samples from: (1) uppermost Peoria Loess (1 m depth below Brady soil) at Bignell Hill, (2) upper (1.5 $\mathrm{m}$ depth below modern soil horizon) and lower (15.5 $\mathrm{m}$ depth) portions of Peoria Loess at the Eustis section, (3) upper Peoria Loess near North Loup, and (4) upper (6.6-7.0 m below the land surface depth) and lower (35.9 m below land surface) portions of Peoria Loess at the Devils Den section.

Age populations of zircons from Bignell Hill mostly are ca. 12-36 Ma and 1.0-1.1, 1.4-1.5, and $1.65-1.75 \mathrm{Ga}$, plus three grains that are ca. $2.7 \mathrm{Ga}$. This age distribution pattern is similar to loess collected at Eustis, particularly the lower (i.e., older) sample (compare Figs. 8A and 8B). Zircons from upper and lower Peoria Loess samples at Eustis (Euz and Elz, respectively) have similar age distributions, although only sample Euz has Archean zircons, and only sample Elz has many grains in the range of ca. 300 to $600 \mathrm{Ma}$. In general, the relative probability curve for lower Eustis resembles the curve for Platte River sediment, whereas the curve for upper Eustis more closely approximates the White River Group age distribution pattern.
Both samples contain a significant component of Tertiary material, in agreement with the $\mathrm{K}$-feldspar $\mathrm{Pb}$ isotope data. However, contrary to the $\mathrm{U}-\mathrm{Pb}$ zircon results, $\mathrm{Pb}$ isotope data from K-feldspars suggest an increasing Platte River component upsection at Eustis. This apparent contradiction is discussed below.

On the north side of the Platte River, zircons from Peoria Loess at the Devils Den and North Loup localities have age distribution patterns that are similar to those of loess from south of the river. At North Loup, zircons from upper Peoria Loess range in age from ca. 10 to $45 \mathrm{Ma}$, with major peaks at ca. $34 \mathrm{Ma}$ (age of the White River Group) and ca. 25-30 Ma, plus three Proterozoic age groups of ca. 1.05-1.15, 1.4, 1.65$1.75 \mathrm{Ga}$, and two grains at ca. 2.7 Ga (Fig. 9A). Zircons from upper and lower Devils Den samples (DDuz and DDlz, respectively) have age distribution patterns similar to each other, but with subtle differences (Fig. 9B). There are more zircons with ages younger than $30 \mathrm{Ma}$ in the lower Devils Den sample, whereas the dominant population of young zircons in the upper Devils Den sample is ca. 34 Ma. Also, although 

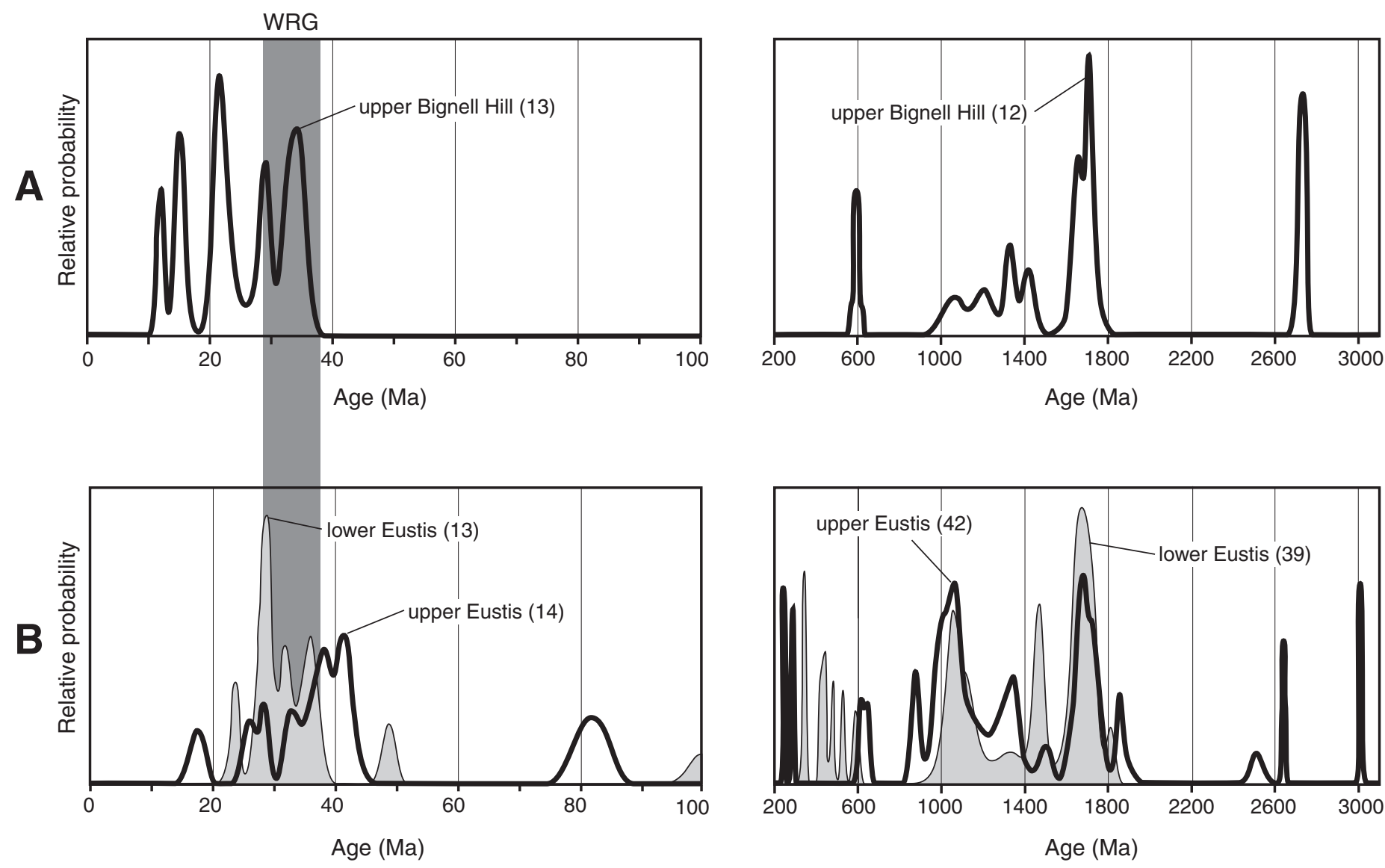

Figure 8. Relative probability curves showing age distributions of detrital zircons from Peoria Loess samples located south of the Platte River in central Nebraska. (A) Upper Bignell Hill, just below the Brady paleosol (sample BH-2). (B) Eustis samples (upper Peoria-EUZ; lower Peoria-ELZ). In this and subsequent figures that contain results from multiple samples, data from the stratigraphically higher sample are shown as a thick curve, whereas data from the lower sample are shown as a shaded curve. The darker shaded vertical band represents the time span of the White River Group (WRG), ca. 28-37 Ma.

both samples have many grains in the range of 1.0 to $1.8 \mathrm{Ga}$, the dominant age population in lower Peoria at Devils Den is ca. 1.65-1.7 Ga, whereas the dominant age group in the upper Peoria sample is at ca. $1.70-1.80 \mathrm{Ga}$. The slight differences between the upper and lower parts of the Devils Den section mirror the minor differences that occur in zircon age groups at upper and lower Eustis. In both sections, the data suggest a predominately Platte River source for the lower loess and a predominately White River Group source for the upper part of the section. However, one significant difference between samples from north and south of the Platte is that the southern locations (at Eustis and Bignell Hill) have a 300- to 600-Ma component that also appears in the Platte River terrace samples. In contrast, zircons of this age are rare or lacking altogether from samples collected north of the Platte (at Devils Den and North Loup) and form only a minor component in the South Dakota White River Group sample.

\section{Potential Sources of Loess in Northeastern Nebraska and Northwestern Iowa}

$\mathrm{Pb}$ isotope compositions of $\mathrm{K}$-feldspars from loess of northeastern Nebraska and western Iowa are distinct from those of central Nebraska loess (Fig. 5), suggesting that this silt had a different source. During the time of Peoria Loess deposition in Nebraska, the Laurentide Ice Sheet had progressed at least as far south as southern North Dakota (Clayton and Moran, 1982) and would have provided outwash silts to the Missouri River. We suggest the possibility that outwash from this large glacial body could have supplied the silt in loess deposited immediately to the south and southeast of the ice front. However, this interpretation is difficult to test because, as discussed earlier, we were unable to locate siltrich outwash terrace deposits of unequivocal late Wisconsin origin on the Missouri River between Nebraska and South Dakota. Instead, we analyzed detrital zircons from a till sample collected in the southernmost part of the James Lobe in South Dakota, and a loess sample on the south side of the Missouri River $40 \mathrm{~km}$ south of the till locality.

In contrast to zircons from the Platte River terrace samples and the White River Group, only one zircon (ca. 27 Ma, Table DR1 [see footnote 1]) of possible White River age was found in the Wisconsin till sample; the typical White River zircon age at $34 \mathrm{Ma}$ is missing altogether (Figs. 10A and 10B). Several grains are in the age range of ca. 60 to $100 \mathrm{Ma}$. Amongst the older zircons, the most significant age populations are $1.6-1.8$ and $2.6-3.2 \mathrm{Ga}$; minor age groups are present at 500-600 Ma, 1.0-1.2, 1.5, 2.0 , and $2.35 \mathrm{Ga}$. This age distribution pattern is very different from zircons in central Nebraska loess and possible western sources discussed earlier. However, the ages of zircons in the till are consistent with studies that report the predominant lithologies of till from the James Lobe (Hallberg and Kemmis, 1986). 

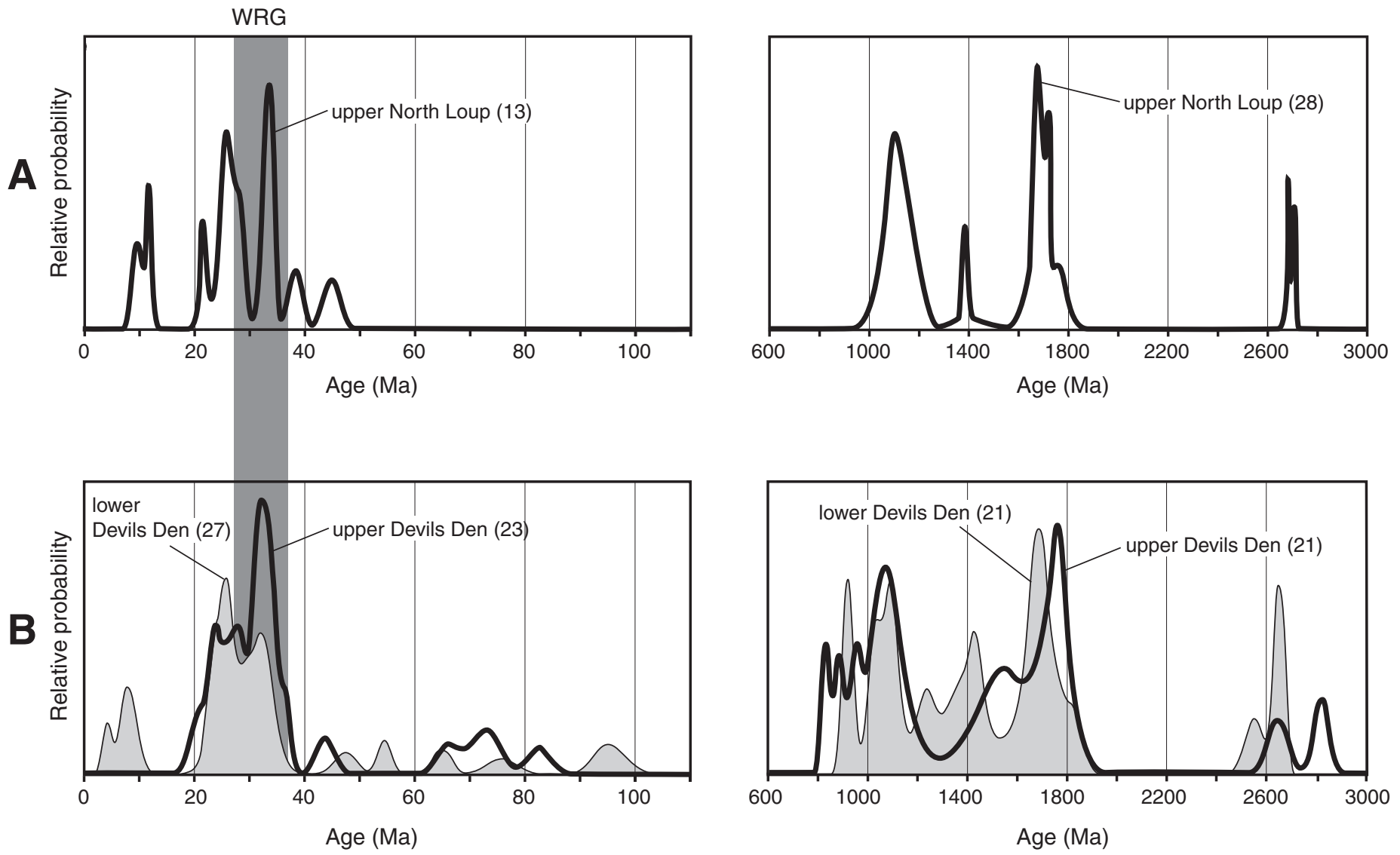

Figure 9. Relative probability curves showing age distributions of detrital zircons from Peoria Loess samples located north of the Platte River in central Nebraska. WRG-White River Group. (A) Upper Peoria Loess near North Loup (sample NE-516). (B) Devils Den samples (upper Peoria Loess-DDUZ; lower Peoria Loess-DDLZ).

\section{Detrital Zircon Ages of Peoria Loess from Northeastern Nebraska and Northwestern Iowa}

Two samples of upper Peoria Loess were collected from northeastern Nebraska and western Iowa (Fig. 2). Sample NE-559 occurs just south of the Missouri River near Oberg, Nebraska; sample SC-1 is from Sioux City, Iowa. Young zircons from NE-559 range in age from ca. 20 to $95 \mathrm{Ma}$. Older grains are ca. $600 \mathrm{Ma}$, plus there are broad ranges of ages at 1.0-2.0 Ga and 2.35-2.9 Ga (Fig. 10A). A similar distribution of ages occurs in the sample from Sioux City (Fig. 10B); young zircons are ca. 50-125 Ma, whereas older zircons are ca. 1.0-2.0, 2.35, and 2.7 Ga. Zircon ages from both loess samples are in general agreement with ages of zircons from the James Lobe till sample. These data support an interpretation that Peoria Loess in northeastern Nebraska and western Iowa has a different source than loess from central Nebraska. Thus, although most of the Peoria Loess in Nebraska is primarily of
Tertiary volcanogenic sedimentary (i.e., nonglaciogenic) origin, a small percentage of the loess, mostly in northeastern Nebraska, is in fact glacially derived from the southern margin of the Laurentide Ice Sheet. This conclusion is supported by loess thickness trends (Mason, 2001) and by geochemical analysis (Muhs et al., 2008).

Two zircon samples were collected from Peoria Loess at Loveland, Iowa, immediately east of the Missouri River (Fig. 2). The lower Loveland sample contains young zircons that range in age from ca. 24 to 70 and 160 to $190 \mathrm{Ma}$ (Fig. 10C). Young zircons in the upper Loveland sample are concentrated between ca. 50 and $120 \mathrm{Ma}$. Older age populations of zircons from the lower Loveland sample are 350-430 Ma, 1.0-1.8 and 2.4-2.8 Ga; upper Loveland zircons are somewhat different, with ages of ca. 200,350, and $580 \mathrm{Ma}$, plus 1.0-1.2, 1.4-1.5, 1.6-1.8, 2.3, and $2.8 \mathrm{Ga}$. These age groups resemble those from the James Lobe till sample (Figs. 10A and $10 \mathrm{~B}$ ), and are distinctly different from zir- con ages from the Platte River and White River Group. Muhs and Bettis (2000) subdivided the Loveland section on the basis of grain size, showing that the upper $20 \mathrm{~m}$ of Peoria Loess at Loveland was finer grained. They hypothesized that upper Peoria Loess at Loveland contains more of a distal (i.e., finer grained) component than the lower portion. They suggested that this component was derived from the same source as Peoria Loess of central Nebraska. In contrast, our new data suggest the source of most of the loess at Loveland, and elsewhere in western Iowa and in northeastern Nebraska, was the Missouri River, which drained the Laurentide Ice Sheet. Because we find no zircons of White River Group age, we suspect that the change in loess grain size is due to the increase of a different, as yet unidentified, source. Alternatively, the finer grain size could reflect differences in wind strength rather than provenance (see Discussion below). No Pb isotope data are currently available from detrital K-feldspars of the Loveland section of Peoria Loess. 

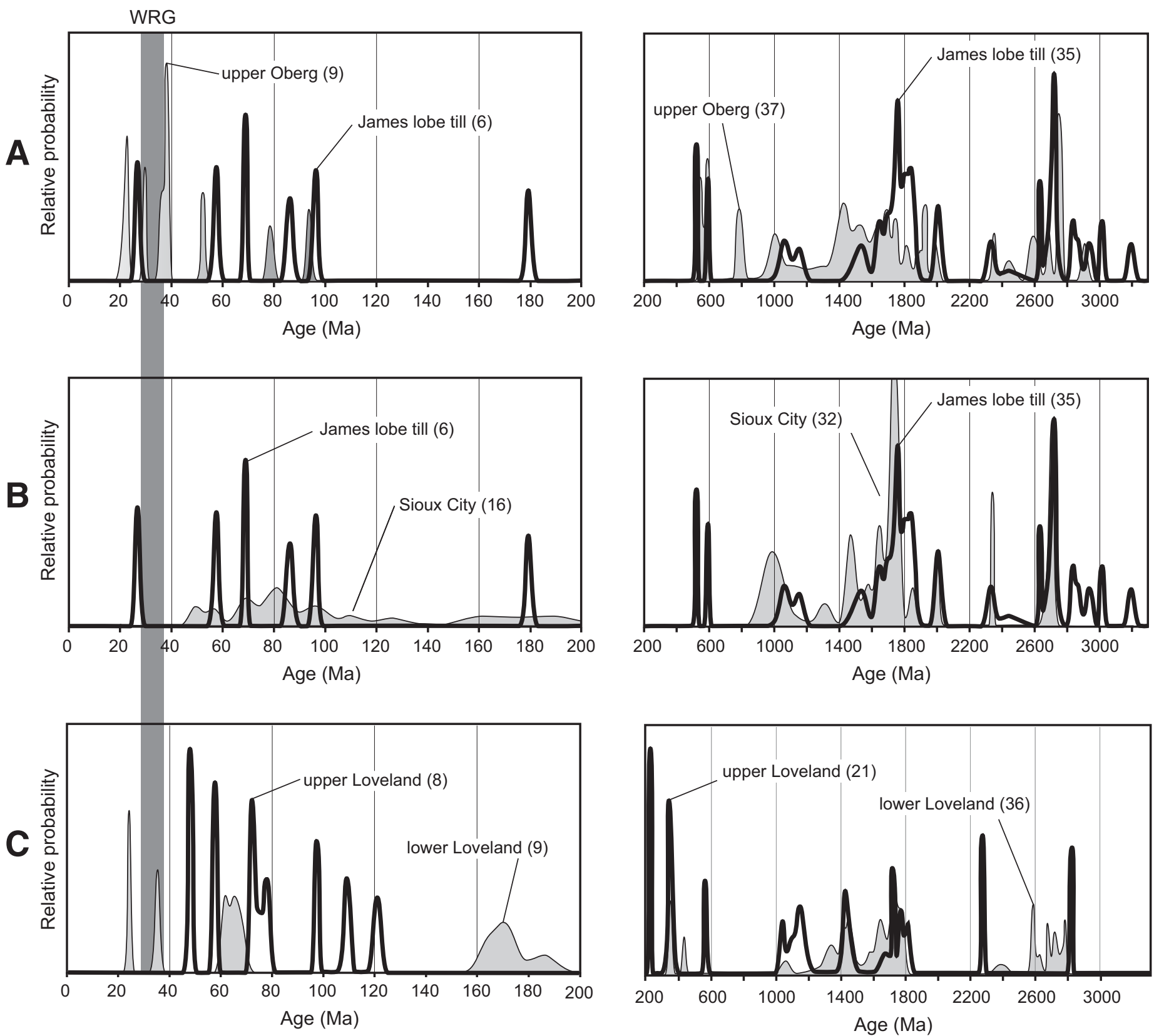

Figure 10. Relative probability curves showing age distributions of detrital zircons from Peoria Loess samples located in northeastern Nebraska and western Iowa. Also shown is a relative probability curve for zircons from a till sample (SD-3) from just south of the James Lobe of the Laurentian Ice Sheet. WRG-White River Group. (A) Upper Peoria Loess near Oberg (sample NE-559), located just south of the Missouri River. (B) Upper Peoria Loess near Sioux City, Iowa (sample SC-1). (C) Loveland, Iowa, samples (upper Peoria LoessL-1-98; lower Peoria Loess-L-1-00). 


\section{DISCUSSION}

\section{Source of Peoria Loess in Central Nebraska}

On the basis of the potential availability of silt, we hypothesize that the two most likely sources of Peoria Loess in central Nebraska are Platte River sediments and (or) poorly consolidated Tertiary White River Group volcanogenic rocks in the central Great Plains. The Nebraska Sand Hills (Quaternary) and sandy and conglomeratic Tertiary rocks that crop out in the upper Great Plains (such as the Arikaree and Ogallala Groups) contain much less silt, but might be minor contributors.

The fields of data for $\mathrm{Pb}$ isotope ratios in K-feldspars of the White River Group, Platte River alluvium of Late Wisconsin age, Pliocene sand sheet silt, and the Nebraska Sand Hills are distinct, making it possible to discriminate between these potential loess sources. $\mathrm{Pb}$ isotope data show that most upper Peoria Loess from central Nebraska was derived from a young source, probably the White River Group. A few samples of Peoria Loess, collected near the Platte River, contain K-feldspars with $\mathrm{Pb}$ isotope ratios similar to K-feldspars in the Platte. These K-feldspars were derived ultimately from Mesoproterozoic crystalline rocks of the Colorado province (Aleinikoff et al., 1993). Loess thickness trends, modeled using inversedistance weighted interpolation (Mason, 2001), confirm our recognition of loess sources. Deviations from this trend, calculated as large positive residuals that imply underestimated thicknesses, occur only near the Platte and Missouri Rivers. As shown above, Peoria Loess in northeastern Nebraska and western Iowa has different isotopic characteristics than loess in central and western Nebraska, a finding in agreement with the data of Mason (2001). Interpretations of loess sources from isotopic data are also consistent with particle size and geochemical data (Muhs et al., 2008).

Interpretations based on $\mathrm{U}-\mathrm{Pb}$ ages of detrital zircons from the Platte River, Pliocene sand sheet, and White River Group are equivocal. Most of the $\mathrm{U}-\mathrm{Pb}$ ages of zircons from Platte River terrace and Pliocene sand sheet samples are similar to zircons from the White River Group. However, tephras from the White River Group are dated at ca. 28-34 Ma (Zielinski and Naeser, 1977; Obradovich et al., 1995; Larson and Evanoff, 1998). Thus, zircons younger than $28 \mathrm{Ma}$ postdate the White River Group. As shown in Figure 7B and Table DR2, we dated several young zircons from Platte River terrace and Pliocene sand sheet samples, ranging in age from ca. 5 to $28 \mathrm{Ma}$. All samples have many zircons of Proterozoic (1.0-1.9 Ga) age.
Because both fluvial and eolian processes occurred simultaneously during loess deposition in the late Wisconsin, we are unable to construct a unique interpretation of the sequence of events from the zircon data alone. Based on the K-feldspar $\mathrm{Pb}$ isotope data, we conclude that most of the silt in Peoria Loess of central Nebraska was ultimately derived from the White River Group. However, we do not fully understand the interplay of possible sources during loess accumulation. U-Pb zircon data suggest that the oldest Peoria Loess was derived, at least in part, from the Platte River, because of the presence of young (post-White River Group) zircons. Presumably, these grains were derived from areas upstream of our samples, along reaches of the South Platte and North Platte Rivers and their tributaries. However, it is also possible that these zircons were deposited in the Wisconsin terrace sediments by the same eolian process that deposited loess to the north and south of the Platte. For example, a belt of Arikaree Group rocks crops out just south of the White River Group exposures in southern South Dakota. The weathered upper parts of these sediments may have been available for eolian transport prior to destabilization and erosion of the White River Group.

Although U-Pb ages of detrital zircons in Peoria Loess do not provide a unique solution to the determination of source (and therefore paleowind direction), the combination of a number of independent parameters strongly indicate that paleowinds during the late Wisconsin were from the west. Peoria Loess thickness (Swinehart et al., 1994a; Mason, 2001) and fine silt $(20-2 \mu \mathrm{m})$ and clay $(<2 \mu \mathrm{m})$ content (Muhs et al., 2008) generally decrease from northwest to southeast across Nebraska. Our U-Pb isotopic data suggest that the White River Group was the primary source of the Peoria Loess, supporting the interpretation of westerly or northwesterly paleowinds. $\mathrm{Pb}$ isotope data from K-feldspars provide an additional constraint, indicating that the Platte could not have been a significant source for most of the Peoria Loess of central Nebraska. We conclude that Peoria Loess in central Nebraska was derived ultimately by deflation from the White River Group in South Dakota, with only minor contributions from the Platte River. The interpretation of a White River Group source for Peoria Loess in central Nebraska obviates the need for an ancestral Platte River to the north of the loess deposits, as proposed by Winspear and Pye (1995). This hypothesis is also questionable because there is no geomorphic or subsurface information supporting a large paleovalley for the Platte River. Indeed, the presence of late Wisconsin terraces along the modern Platte River valley implies no major change in drainage position (Swine- hart et al., 1994a). We emphasize, however, that eolian silt transport from areas of the White River Group to central Nebraska may have been a multi-stage process. Muhs et al. (2008) show that the coarse silt content of central Nebraska loess is relatively high. Transport of coarse particles by wind may have been through the Nebraska Sand Hills, as envisioned by Mason (2001) and Mason et al. (2003) and described by Muhs et al. (2008). Nevertheless, the Pb isotope data from K-feldspars shown here demonstrate that the Nebraska Sand Hills provided little material to the loess.

\section{Variations of Peoria Loess in Vertical Sections}

$\mathrm{Pb}$ isotope compositions of $\mathrm{K}$-feldspars in the vertical section of Peoria Loess Eustis display both sample-to-sample variation and general trends from the bottom to the top of the section. Nearly all of the $\mathrm{Pb}$ isotope data plot within the field of isotopic ratios from the White River Group $\left({ }^{206} \mathrm{~Pb} /{ }^{204} \mathrm{~Pb}\right.$ of most samples range from ca. 18.2 to 18.9). Overall, the ratios appear to decrease slightly with decreasing age of the loess (Fig. 6). A possible cause for this decrease is an increased component of Platte River sediment that contains $\mathrm{K}$-feldspars with $\mathrm{Pb}$ isotope ratios in the range of ca. 17.6 to 18.2. However, this interpretation is contrary to U-Pb age data from detrital zircons that suggest more of a Platte River component in the lower portion of the section. More work is needed to resolve this issue.

\section{Paleoclimatic Implications}

The identification of White River Group sediments as the primary source of Peoria Loess for most of central and western Nebraska has important paleoclimatic implications. There has long been a debate about "glacial loess" versus "desert loess," i.e., non-glaciogenic loess (see reviews in Smalley and Krinsley, 1978; Pye, 1995; Wright, 2001; and Muhs and Bettis, 2003). The White River Group as the source for Peoria Loess of central and western Nebraska implies very dry, windy, and sparsely vegetated conditions in the northern Great Plains during the last glacial period, with abundant non-glacial silt transported in the atmosphere. Since the late Wisconsin, the stratigraphic record in the upper Great Plains indicates only modest loess deposition, for example, at Bignell Hill, $2 \mathrm{~m}$ of loess were deposited in the past $10,000 \mathrm{yr}$, whereas almost $50 \mathrm{~m}$ were deposited during the late Wisconsin (Mason et al., 2003; Miao et al., 2005). At present, little sediment is being eroded by the wind in the region, except through agricultural disturbance (such as during the 1930s Dust Bowl period). Paleoclimatic models simulate 
only modest increases (compared to present) in dust production during the last glacial period in central North America (Andersen et al., 1998; Mahowald et al., 1999; Kohfeld and S.P. Harrison, 2000), yet the largest accumulations (30-50 m) of late Wisconsin loess in the world are found in this region (Swinehart et al., 1994a; Mason, 2001). Thus, models attempting to simulate the high rates of dust deposition recorded in ice cores and deep-sea sediments (Petit et al., 1990; Ruddiman, 1997) need to be modified to accommodate the high rates of non-glaciogenic dust production in central North America. A recent dust model with linked AGCM, biogeography, and biogeochemical models is the first of which we are aware that has successfully generated a non-glacial dust source in the central Great Plains during the last glacial period (Mahowald et al., 2006).

\section{How Far Did the Fine-Grained Component of Peoria Loess Travel?}

Roberts et al. (2003) have shown that unusually high mass accumulation rates of silt occurred between 18 and $14 \mathrm{ka}$ in central and western Nebraska. They propose that this extraordinary amount of atmospheric dust may have been responsible for maintaining the relatively cool late Wisconsin climate for several thousand years longer than what is simulated by paleoclimate models. With such vast amounts of dust in the atmosphere, we consider the question of how far this dust may have traveled.
Biscaye et al. (1997) measured isotopic ratios of $<5 \mu \mathrm{m}$ dust recovered from the GISP2 Greenland ice core, deposited at ca. 26-23 ka. They conclude, on the basis of clay mineralogy and $\mathrm{Pb}, \mathrm{Sr}$, and $\mathrm{Nd}$ isotopic data, that this dust is a mixture of particles derived from China and the Gobi desert. They also analyzed loess from a number of other potential source areas, including two sites in the United States (eastern Washington and western Illinois). Neither of these samples has comparable isotopic compositions to the GISP2 dust. Loesses from the Great Plains of the United States were eliminated as possible sources because they have high smectite content, a clay mineral that is essentially absent from the Greenland dust.

$\mathrm{Pb}$ isotope compositions of GISP2 dust plot in a tight array entirely within the field defined by $\mathrm{Pb}$ isotope compositions from K-feldspars of the White River Group; they are also similar to $\mathrm{Pb}$ isotope ratios for upper Peoria Loess in Nebraska (Fig. 11). It is interesting to speculate, therefore, that the large flux of dust derived from the White River Group may have been deposited as far away as Greenland during the late Wisconsin. However, in addition to the difference in smectite contents of Peoria Loess and Greenland dust, two other factors need to be considered. First, Greenland dust analyzed by Biscaye et al. (1997) was deposited between ca. 26 and $23 \mathrm{ka}$, whereas loess deposition in central Nebraska occurred primarily between ca. 25 and $12 \mathrm{ka}$, with maximum dust flux at 18-14 ka (Roberts et al., 2003). Second, the comparison

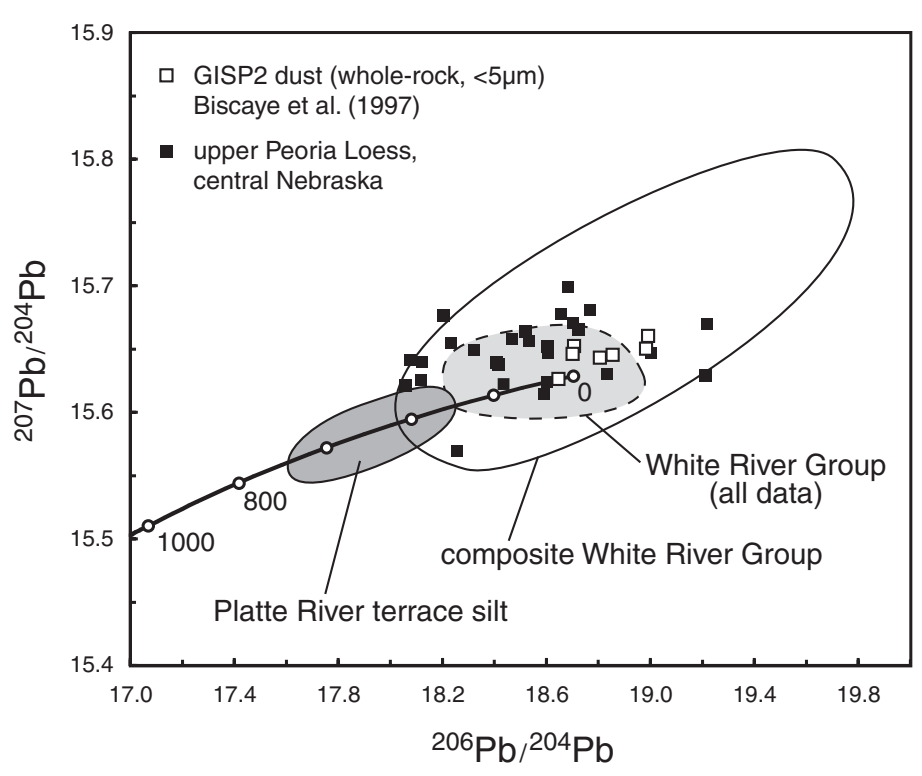

Figure 11. Comparison of $\mathrm{Pb}$ isotope compositions of $\mathrm{K}$-feldspars from Peoria Loess of central Nebraska and $<\mathbf{5} \boldsymbol{\mu m}$ dust from the GISP2 Greenland ice core. we make here comprises $\mathrm{Pb}$ isotope data from different particle size classes and mineralogy, namely, $<5 \mu \mathrm{m}$ whole-rock dust from Greenland (Biscaye et al., 1997) versus <63 $\mu \mathrm{m}$ K-feldspar from Nebraska (this study).

Although the isotopic data from Biscaye et al. (1997) were obtained from whole-rock dust samples deposited several thousand years prior to maximum loess deposition in Nebraska, significant quantities of dust were deposited in Greenland throughout the late Wisconsin glacial period (Meese et al., 1997; Ram and Koenig, 1997). Dust deposited at 18-14 ka would need to be analyzed for both isotopic composition and clay content to evaluate the possibility of a White River source during this time span. Ideally, the isotopic analysis should be made on K-feldspar separates for a more robust comparison. There is no question about the differences in clay mineralogy between Greenland dust (low smectite) and loess in Nebraska (high smectite; see Muhs et al., 2008). However, because smectite aggregates readily, we would not expect long-distance transport of this mineral. We note, for example, that African dust, which is transported annually to the Western Hemisphere, contains little or no smectite (Caquineau et al., 2002) yet smectite is common in source areas for Saharan dust (Areola, 1996). Despite these uncertainties, the complete overlap of $\mathrm{Pb}$ isotope compositions from Greenland dust and Peoria Loess from Nebraska is provocative, and invites more detailed study. We note that calibrated dust modeling permits the possibility of dust transport from North America to Greenland (Mahowald et al., 2006).

\section{CONCLUSIONS}

$\mathrm{U}-\mathrm{Pb}$ ages of zircons and $\mathrm{Pb}$ isotopic compositions in K-feldspars allow us to define three geographically distinct Peoria Loess zones in Nebraska and western Iowa. In southwestern Nebraska and immediately adjacent to the Platte River, Peoria Loess was derived primarily from Platte River fluvial deposits that probably contained a mixture of glaciogenic silt from the Colorado province and non-glaciogenic material from Tertiary volcanogenic rocks. In the broad area of central Nebraska (where loess accumulations are the thickest), Peoria Loess was derived primarily from the White River Group (i.e., non-glaciogenic source), with minor input from Platte River sediments. In northeastern Nebraska and western Iowa, Peoria Loess was derived primarily from glaciogenic sediments transported in the Missouri River. Thus, the primary source for most of the late Wisconsin loess in Nebraska is non-glaciogenic, with only a limited amount of material derived by glacial grinding and erosion. 
Ages of detrital zircons in Peoria Loess generally support interpretations of $\mathrm{Pb}$ isotope data from K-feldspars, although there are some complications. Zircon ages of ca. 10-30 Ma suggest that the Ogallala and Arikaree Groups are also potential sources for Peoria Loess in Nebraska. However, because these units are composed mostly of sand- and gravel-size material, they probably contributed only minor amounts of silt. We are unable to use the zircon data alone to determine if the silt was deflated from the White River Group and directly deposited as loess or whether it was fluvially transported and deflated from Platte River or Pliocene sand sheet sediments.

The combination of isotopic data, loess thickness and particle size trends, and geochemistry strongly suggest that loess was transported by northwesterly or westerly paleowinds. Finally, $\mathrm{Pb}$ isotope compositions of K-feldspar in Peoria Loess in the central Great Plains loess suggest the possibility of long-range dust transport from North America to Greenland during the last glacial period, a hypothesis to be tested in future studies.

\section{ACKNOWLEDGMENTS}

This research was supported by the Earth Surface Dynamics Program of the U.S. Geological Survey and National Science Foundation grant EAR 00-87572 to Bettis. We thank the Research School of Earth Sciences, Australian National University, for access to the ion microprobe for zircon analyses. We thank K. Chamberlain (University of Wyoming) for analyzing the K-feldspar samples from silt of the Pliocene sand sheet. J. Been, T. Frolking, and R. Sauer assisted in field work. J. Mason, T. Hinkley, D. Gaylord, M. Soreghan, N. Mahowald, S. Hovan, and J. Amato provided thorough critical reviews of earlier drafts of the paper.

\section{REFERENCES CITED}

Aleinikoff, J.N., Reed, J.C., Jr., and Wooden, J.L., 1993, Lead isotopic evidence for the origin of Early and Middle Proterozoic rocks of the Colorado Province: Precambrian Research, v. 63, no. 1-2, p. 97-122, doi: 10.1016/0301-9268(93)90007-O.

Aleinikoff, J.N., Muhs, D.R., Sauer, R.R., and Fanning, C.M., 1999, Late Quaternary loess in northeastern Colorado, II: $\mathrm{Pb}$ isotopic evidence for the variability of loess sources: Geological Society of America Bulletin, v. 111, p. 1876-1883, doi: 10.1130/0016-7606(1999)1 $11<1876$ :LQLINC>2.3.CO;2.

Andersen, K.K., Armengaud, A., and Genthon, C., 1998, Atmospheric dust under glacial and interglacial conditions: Geophysical Research Letters, v. 25, p. 2281-2284, doi: 10.1029/98GL51811.

Andersen, T., 2005, Detrital zircons as tracers of sedimentary provenance: Limiting conditions from statistics and numerical simulation: Chemical Geology, v. 216, p. 249-270, doi: 10.1016/j.chemgeo.2004.11.013.

Areola, O., 1996, Soils, in Adams, W.M., Goudie, A.S., and Orme, A.R., eds., The physical geography of Africa: Oxford, Oxford University Press, p. 134-147.

Bell, K., and Murton, J.B., 1995, A new indicator of glacial dispersal: Lead isotopes: Quaternary Science Reviews, v. 14, p. 275-287, doi: 10.1016/0277-3791(95)00007-C.

Bettis, E.A., III, Muhs, D.R., Roberts, H.M., and Wintle, A.G., 2003a, Last glacial loess in the conterminous U.S.A:
Quaternary Science Reviews, v. 22, p. 1907-1946, doi: 10.1016/S0277-3791(03)00169-0.

Biscaye, P.E., Grousset, F.E., Reve, M., Van der Gaast, S. Zielinski, G.A., Vaars, A., and Kukla, G., 1997, Asian provenance of glacial dust (stage 2) in the Greenland Ice Sheet Project 2 ice core, Greenland: Journal of Geophysical Research, v. 102, n. C12, p. 26,765-26,781, doi: 10.1029/97JC01249.

Bryan, K., 1945, Glacial versus desert origin of loess: American Journal of Science, v. 243, p. 245-248.

Caquineau, S., Gaudichet, A., Gomes, L., and Legrand, M., 2002, Mineralogy of Saharan dust transported over northwestern tropical Atlantic Ocean in relation to source: Journal of Geophysical Research, v. 107, no. D15, 12 p.

Clayton, L., and Moran, S.R., 1982, Chronology of late Wisconsin glaciation in middle North America: Quaternary Science Reviews, v. 1, p. 55-82, doi: 10.1016/ 0277-3791(82)90019-1.

COHMAP (Cooperative Holocene Mapping Project) Members, 1988, Climatic changes of the last 18,000 years: Observations and model simulations: Science, v. 241, p. 1043-1052, doi: 10.1126/science.241.4869.1043.

Condra, G.E., Reed, E.C., and Gordon, E.D., 1950, Correlation of the Pleistocene deposits of Nebraska: Nebraska Geological Survey Bulletin, no. 15A, 74 p.

Dodson, M.H., Compston, W., Williams, I.S., and Wilson, J.F., 1988, A search for ancient detrital zircons in Zimbabwean sediments: Journal of the Geological Society, v. 145 , p. 977-983, doi: $10.1144 /$ gsjgs. 145.6 .0977 .

Fedo, C.M., Sircombe, K.N., and Rainbird, R.H., 2003, Detrital zircon analysis of the sedimentary record, in Hanchar, J.M., and Hoskin, P.W.O., eds., Zircon: Reviews in mineralogy and geochemistry: Washington, D.C., Mineralogical Society of America, v. 53, p. 277-303.

Flint, R.F., 1971, Glacial and Quaternary Geology: New York, Wiley \& Sons, $906 \mathrm{p}$

Goldich, S.S., 1938, A study in rock weathering: The Journal of Geology, v. 46, p. 17-58.

Hallberg, G.R., and Kemmis, T.J., 1986, Stratigraphy and correlation of the glacial deposits of the Des Moines and James Lobes and adjacent areas in North Dakota, South Dakota, Minnesota, and Iowa: Quaternary Science Reviews, v. 5, p. 65-68, doi: 10.1016/0277-3791(86)90175-7.

Harvey, L.D.D., 1988, Climatic impact of ice-age aerosols: Nature, v. 334, p. 333-335, doi: 10.1038/334333a0.

Hovan, S.A., Rea, D.K., Pisias, N.G., and Shackleton, N.J., 1989, A direct link between the China loess and marine $\delta^{18} \mathrm{O}$ records: Aeolian flux to the north Pacific: Nature, v. 340, p. 296-298, doi: 10.1038/340296a0.

Hughes, T., 1992, Abrupt climatic change related to unstable ice-sheet dynamics: Toward a new paradigm: Palaeogeography, Palaeoclimatology, Palaeoecology, v. 97, p. 203-234, doi: 10.1016/0031-0182(92)90209-N

Jacobs, P.M., and Mason, J.A., 2007, Late Quaternary climate change, loess sedimentation, and soli profile development in the central Great Plains: A pedosedimentary model: Geological Society of America Bulletin, v. 119, p. 462-475, doi: 10.1130/B25868.1.

Kohfeld, K.E., and Harrison, S.P., 2000, How well can we simulate past climates? Evaluating the models using global palaeoenvironmental datasets: Quaternary Science Reviews, v. 19, p. 321-346, doi: 10.1016/S02773791(99)00068-2.

Kohfeld, K.E., and Harrison, S.P., 2001, DIRTMAP: The geological record of dust: Earth-Science Reviews, v. 54, p. 81-114, doi: 10.1016/S0012-8252(01)00042-3.

Krogh, T.E., 1973, A low-contamination method for hydrothermal decomposition of zircon and extraction of $\mathrm{U}$ and $\mathrm{Pb}$ for isotopic age determination: Geochimica et Cosmochimica Acta, v. 37, p. 485-494, doi: 10.1016/0016-7037(73)90213-5.

Larson, E.E., and Evanoff, E., 1998, Tephrostratigraphy and source of the tuffs of the White River sequence: Geological Society of America Special Paper 325, p. 1-14

Ludwig, K.R., 2001, Squid, version 1.02, A user's manual: Berkeley Geochronology Center Special Publication No. 2, 19 p.

Ludwig, K.R., 2003, Isoplot 3.0: A geochronological toolkit for Microsoft Excel: Berkeley Geochronology Center Special Publication No. 4, $73 \mathrm{p}$.

Lugn, A.L., 1939, Nebraska in relation to the problems of Pleistocene stratigraphy: American Journal of Science, v. 237 , p. $851-884$.
Lugn, A.L., 1968, The origin of loesses and their relation to the Great Plains in North America, in Schultz, C.B., and Frye, J.C., eds., Loess and related eolian deposits of the world: Lincoln, University of Nebraska Press, p. 139-182.

Madole, R.F., 1991a, Surficial geologic map of the Walden $30^{\prime}$ $\times 60^{\prime}$ quadrangle, Jackson, Larimer, and Routt Counties, Colorado: U.S. Geological Survey Miscellaneous Investigations Series Map I-1824, scale 1:100,000, 1 sheet.

Madole, R.F., 1991b, Surficial geologic map of the Steamboat Springs $30^{\prime} \times 60^{\prime}$ quadrangle, Grand, Jackson, and Routt Counties, Colorado: U.S. Geological Survey Miscellaneous Investigations Series Map I-1825, scale $1: 100,000,1$ sheet.

Madole, R.F., VanSistine, D., and Michael, J.A., 1998, Glaciation in the upper Platte River drainage basin, Colorado: U.S. Geological Survey Geologic Investigations Series Map I-2644.

Mahowald, N., Kohfeld, K., Hansson, M., Balkanski, Y. Harrison, S.P., Prentice, I.C., Schulz, M., and Rodhe, H., 1999, Dust sources and deposition during the last glacial maximum and current climate: A comparison of model results with paleodata from ice cores and marine sediments: Journal of Geophysical Research, v. 104, p. 15,895-15,916, doi: 10.1029/1999JD900084.

Mahowald, N.M., Muhs, D.R., Levis, S., Rasch, P.J., Yoshioka, M., Zender, C.S., and Luo, C., 2006, Change in atmospheric mineral aerosols in response to climate: Last glacial period, preindustrial, modern, and doubled carbon dioxide climates: Journal of Geophysical Research, v. 111, D10202, 22 p.

Martin, C.W., 1993, Radiocarbon ages on late Pleistocene loess stratigraphy of Nebraska and Kansas, central Great Plains, U.S.A: Quaternary Science Reviews, v. 12, p. 179-188, doi: 10.1016/0277-3791(93)90052-N.

Mason, J.A., 2001, Transport direction of Peoria Loess in Nebraska and implications for loess sources on the central Great Plains: Quaternary Research, v. 56, p. 79-86, doi: 10.1006/qres.2001.2250.

Mason, J.A., Jacobs, P.M., Hanson, P.R., Miao, X., and Goble, R.J., 2003, Sources and paleoclimatic significance of Holocene Bignell Loess, central Great Plains, USA: Quaternary Research, v. 60, p. 330-339, doi: 10.1016/j.yqres.2003.07.005.

Mears, B., Jr., 2001, Glacial records in the Medicine Bow Mountains and Sierra Madre of southern Wyoming and adjacent Colorado, with a traveler's guide to their sites: Public Information Circular-Geological Survey of Wyoming Report 41, 26 p.

Meese, D.A., Gow, A.J., Alley, R.B., Zielinski, G.A. Grootes, P.M., Ram, M., Taylor, K.C., Mayewski, P.A., and Bolzan, J.F., 1997, The Greenland Ice Sheet Project 2 depth-age scale: Methods and results: Journal of Geophysical Research, v. 102, no. C12, p. 26,41126,423, doi: 10.1029/97JC00269.

Miao, X., Mason, J.A., Goble, R.J., and Hanson, P.R., 2005 Loess record of dry climate and aeolian activity in the early- to mid-Holocene, central Great Plains, North America: The Holocene, v. 15, no. 3, p. 339-346, doi 10.1191/0959683605hl805rp.

Muhs, D.R., and Bettis, E.A., III, 2000, Geochemical variations in Peoria Loess of western Iowa indicate paleowinds of midcontinental North America during last glaciation: Quaternary Research, v. 53, p. 49-61, doi: 10.1006/qres.1999.2090.

Muhs, D.R., and Bettis, E.A., III, 2003, Quaternary loesspaleosol sequences as examples of climate-driven sedimentary extremes, in Chan, M.A., and Archer, A.W., eds., Extreme depositional environments: Mega end members in geologic time: Boulder, Colorado, Geological Society of America Special Paper 370, p. 53-74.

Muhs, D.R., and Budahn, J.R., 2006, Geochemical evidence for the origin of late Quaternary loess in central Alaska: Canadian Journal of Earth Sciences, v. 43, p. 323-337, doi: 10.1139/E05-115.

Muhs, D.R., Aleinikoff, J.N., Stafford, T.W., Jr., Kihl, R., Been, J., Mahan, S., and Cowherd, S.D., 1999a, Late Quaternary loess in northeastern Colorado, I: Age and paleoclimatic significance: Geological Society of America Bulletin, v. 111, p. 1861-1875, doi: 10.1130/ 0016-7606(1999)111<1861:LQLINC>2.3.CO;2.

Muhs, D.R., Swinehart, J.B., Loope, D.B., Aleinikoff, J.N., and Been, J., 1999b, 200,000 years of climate change 
recorded in eolian sediments of the High Plains of eastern Colorado and western Nebraska, in Lageson, D.R. Lester, A.P., and Trudgill, B.D., eds., Colorado and adjacent areas: Boulder, Colorado, Geological Society of America Field Guide 1, p. 71-91.

Muhs, D.R., Bettis, E.A., III, Aleinikoff, J.N., McGeehin, J.B., Skipp, G., Marshall, B.D., Roberts, H.M., Johnson, W.C., and Benton, R., 2008, Origin and paleoclimatic significance of late Quaternary loess in Nebraska Evidence from stratigraphy, chronology, sedimentology, and geochemistry: Geological Society of America Bulletin, doi: 10.1130/B26221.1 (in press).

Myers, M., 1993, A Pliocene sand sheet beneath the Nebraska Sand Hills [M.S. thesis]: Lincoln, University of Nebraska.

Obradovich, J.D., Evanoff, E., and Larson, E.E., 1995, Revised single-crystal laser-fusion ${ }^{40} \mathrm{Ar} /{ }^{39} \mathrm{Ar}$ ages of Chadronian tuffs in the White River Formation of Wyoming: Geological Society of America Abstracts with Programs, v. 27, p. 77-78.

Overpeck, J., Rind, D., Lacis, A., and Healy, R., 1996, Possible role of dust-induced regional warming in abrup climate change during the last glacial period: Nature, v. 384, p. 447-449, doi: 10.1038/384447a0.

Petit, J.R., Mounier, L., Jouzel, J., Korotkevich, Y.S., Kotlyakov, V.I., and Lorius, C., 1990, Palaeoclimatological and chronological implications of the Vostok core dust record: Nature, v. 343 , p. 56-58, doi: 10.1038 / $343056 \mathrm{a} 0$.

Pye, K., 1987, Aeolian dust and dust deposits: San Diego, California, Academic Press, $334 \mathrm{p}$

Pye, K., 1995, The nature, origin and accumulation of loess: Quaternary Science Reviews, v. 14, p. 653-657, doi 10.1016/0277-3791(95)00047-X.

Ram, M., and Koenig, G., 1997, Continuous dust concentration profile of pre-Holocene ice from the Greenland Ice Sheet Project 2 ice core: Dust stadials, interstadials, and the Eemian: Journal of Geophysical Research, v. 102 n. C12, p. 26,641-26,648, doi: 10.1029/96JC03548.

Reed, E.C., 1968, Loess deposition in Nebraska, in Schultz, C.B., and Frye, J.C., eds., Loess and related eolian deposits of the world: Lincoln, University of Nebraska Press, p. 139-182.

Roberts, H.M., Muhs, D.R., Wintle, A.G., Duller, G.A.T., and Bettis, E.A., III, 2003, Unprecedented last-glacial mass accumulation rates determined by luminescence dating of loess from western Nebraska: Quaternary Research, v. 59, p. 411-419, doi: 10.1016S0033-5894(03)00040-1.

Ruddiman, W.F., 1997, Tropical Atlantic terrigenous fluxes since 25,000 yrs B.P: Marine Geology, v. 136 , p. 189-207, doi: 10.1016/S0025-3227(96)00069-2.

Ruhe, R.V., 1983, Depositional environment of late Wisconsin loess in the midcontinental United States, in Wright, H.E., Jr., and Porter, S.C., eds., Late-Quaternary environments of the United States Volume 1 the late Pleistocene: Minneapolis, University of Minnesota Press, p. 130-137.

Smalley, I.J., and Krinsley, D.H., 1978, Loess deposits associated with deserts: CATENA, v. 5, p. 53-66, doi: 10.1016/S0341-8162(78)80006-X

Smalley, I.J., and Leach, J.A., 1978, The origin and distribution of the loess in the Danube Basin and associated regions of East-central Europe: A review: Sedimentary Geology, v. 21, p. 1-26, doi: 10.1016/0037-0738(78)90031-3.

Stacey, J.S., and Kramers, J.D., 1975, Approximation of terrestrial lead isotope evolution by a two-stage model: Earth and Planetary Science Letters, v. 26, p. 207-226, doi: 10.1016/0012-821X(75)90088-6.

Steiger, R.H., and Jäger, E., 1977, Subcommission on geochronology, convention on the use of decay constants in geo- and cosmochronology: Earth and Planetary Science Letters, v. 36, p. 359-362, doi: 10.1016/ 0012-821X(77)90060-7.

Sun, J., 2002a, Provenance of loess material and formation of loess deposits on the Chinese Loess Plateau: Earth and Planetary Science Letters, v. 203, p. 845-859, doi: 10.1016/S0012-821X(02)00921-4.

Sun, J., 2002b, Source regions and formation of the loess sediments on the high mountain regions of northwestern China: Quaternary Research, v. 58, p. 341-351, doi: 10.1006/qres.2002.2381

Swineford, A., and Frye, J.C., 1951, Petrography of the Peoria Loess in Kansas: The Journal of Geology, v. 59, p. 306-322.

Swinehart, J.B., and Diffendal, R.F., Jr., 1990, Geology of the pre-dune strata, in Bleed, A., and Flowerday, C., eds., An atlas of the Sand Hills, Resource Atlas No. 5a: Lincoln, Nebraska, University of Nebraska, p. 29-42.

Swinehart, J.B., Dreeszen, V.H., Richmond, G.M., Tipton, M.J., Bretz, R., Steece, F.V., Hallberg, G.R., and Goebel, J.E., 1994a, Quaternary geologic map of the Platte River $4^{\circ} \times 6^{\circ}$ quadrangle, United States: U.S. Geological Survey Miscellaneous Investigations Series Map I-1420 (NK-14), scale 1: 1,000,000.

Swinehart, J., Loope, D., Ponte, M., Mason, J., Helland, P., and Kim, N., 1994b, Paleoenvironments of the Nebraska Sand Hills: Society for Sedimentary Geology Midcontinent Section Field Trip Guidebook, 40 p.

Tegen, I., 2003, Modeling the mineral dust aerosol cycle in the climate system: Quaternary Science Reviews, v. 22, p. 1821-1834, doi: 10.1016/S0277-3791(03)00163-X.

Tegen, I., and Lacis, A.A., 1996, Modeling of particle size distribution and its influence on the radiative properties of mineral dust aerosol: Journal of Geophysical Research, v. 101, p. 19,237-19,244, doi: 10.1029/95JD03610.

Tegen, I., Lacis, A.A., and Fung, I., 1996, The influence on climate forcing of mineral aerosols from disturbed soils: Nature, v. 380, p. 419-422, doi: 10.1038/380419a0

Thorp, J., 1945, Significance of loess in classification of soils: American Journal of Science, v. 243, p. 263-270.

Tsoar, H., and Pye, K., 1987, Dust transport and the question of desert loess formation: Sedimentology, v. 34, p. 139-153, doi: 10.1111/j.1365-3091.1987.tb00566.x.

Tweto, O., 1987, Rock units of the Precambrian basement of Colorado: U.S. Geological Survey Professional Paper 1321-A, $54 \mathrm{p}$.

Van Schmus, W.R., Bickford, M.E., Anderson, J.L., Bender, E.E., Anderson, R.R., Bauer, P.W., Robertson, J.M., Bowring, S.A., Condie, K.C., Denison, R.E., Gilbert, M.C., Grambling, J.A., Mawer, C.K., Shearer, C.K., Hinze, W.J., Karlstrom, K.E., Kisvarsanyi, E.B., Lidiak, E.G., Reed, J.C., Jr., Sims, P.K., Tweto, O., Silver, L.T., Treves, S.B., Williams, M.L., and Wooden, J.L., 1993, Trancontinental Proterozoic provinces, in Reed,
J.C., Jr., Bickford, M.E., Houston, R.S., Link, P.K., Rankin, D.W., Sims, P.K., and Van Schmus, R.W., eds. Precambrian: Conterminous U.S.: Boulder, Colorado, Geological Society of America, The Geology of North America, v. C-2, 657 p.

Vermeesch, P., 2004, How many grains are needed for a provenance study?: Earth and Planetary Science Letters, v. 224, p. 441-451, doi: 10.1016/j.eps1.2004.05.037.

Welch, J.E., and Hale, J.M., 1987, Pleistocene loess in Kansas-Status, present problems, and future considerations, in Johnson, W.C., ed., Quaternary environments of Kansas: Kansas Geological Survey Guidebook Series 5, p. 67-84.

Whitmeyer, S.J., and Karlstrom, K.E., 2007, Tectonic model for the Proterozoic growth of North America: Geosphere, v. 3, no. 4, p. 220-259, doi: 10.1130/GES00055.1.

Williams, I.S., 1998, Chapter 1, U-Th-Pb geochronology by ion microprobe, in McKibben, M.A., Shanks, W.C., III, Ridley, W.I. eds., Applications of microanalytical techniques to understanding mineralizing processes: Reviews in Economic Geology, v. 7, p. 1-35.

Winspear, N.R., and Pye, K., 1995, Textural, geochemical and mineralogical evidence for the origin of Peoria Loess in central and southern Nebraska, USA: Earth Surface Processes and Landforms, v. 20, p. 735-745, doi: 10.1002/esp.3290200805.

Wright, H.E., Jr., 1970, Vegetational history of the Central Plains, in Dort, W., Jr., and Jones, J.K., Jr., eds., Pleistocene and recent environments of the Central Great Plains: Lawrence, University of Kansas Department of Geology Special Publication, p. 157-172.

Wright, J.S., 2001, “Desert" loess versus “glacial” loess: Quartz silt formation, source areas and sediment pathways in the formation of loess deposits: Geomorphology, v. 36, p. 231-256, doi: 10.1016/S0169-555X(00)00060-X.

Yokoo, Y., Nakano, T., Nishikawa, M., and Quan, H., 2004, Mineralogical variation of $\mathrm{Sr}-\mathrm{Nd}$ isotopic and elemental compositions in loess and desert sand from the central Loess Plateau in China as a provenance tracer of wet and dry deposition in the northwestern Pacific: Chemical Geology, v. 204, p. 45-62, doi: 10.1016/ j.chemgeo.2003.11.004

Young, R.W., Carder, K.L., Betzer, P.R., Costello, D.K., Duce, R.A., Ditullio, G.R., Tindale, N.W., Laws, E.A., Uematsu, M., Merrill, J.T., and Feely, R.A., 1991, Atmospheric iron inputs and primary productivity: Phytoplankton responses in the North Pacific: Global Biogeochemical Cycles, v. 5, p. 119-134, doi: 10.1029/91GB00927.

Zhisheng, A., Tunghseng, L., Yanchou, L., Porter, S.C., Kukla, G., Xiahao, W., and Yingming, H., 1990, The long-term paleomonsoon variation recorded by the loess-paleosol sequence in central China: Quaternary International, v. 7-8, p. 91-95, doi: 10.1016/1040-6182(90)90042-3.

Zielinski, R.A., and Naeser, C.W., 1977, Fission-track dates from the White River Formation, Shirley Basin Uranium District, Wyoming: Isochron/West, no. 18, p. 19-20.

MANUSCRIPT ReCEIVED 12 MARCh 2007

Revised Manuscript Received 18 February 2008 Manuscript AcCepted 19 February 2008

Printed in the USA 